Article

\title{
Soil pH Mapping with an On-The-Go Sensor
}

\section{Michael Schirrmann ${ }^{1, *}$, Robin Gebbers ${ }^{1}$, Eckart Kramer ${ }^{2}$ and Jan Seidel ${ }^{3}$}

1 Leibniz-Institute for Agricultural Engineering, Department of Engineering for Crop Production, Max-Eyth-Allee 100, D-14469 Potsdam, Germany; E-Mail: rgebbers@atb-potsdam.de

2 HNEE School for Sustainable Development Eberswalde, Friedrich-Ebert-Str. 28, D-16225

Eberswalde, Germany; E-Mail: Eckart.Kramer@hnee.de

3 Technical University of Dresden, D-01062 Dresden, Germany; E-Mail: seidel_j@gmx.de

* Author to whom correspondence should be addressed; E-Mail: mschirrmann@atb-potsdam.de; Tel.: +49-331-5699-412; Fax: +49-331-5699-849.

Received: 11 November 2010; in revised form: 23 December 2010 / Accepted: 29 December 2010 / Published: 7 January 2011

\begin{abstract}
Soil $\mathrm{pH}$ is a key parameter for crop productivity, therefore, its spatial variation should be adequately addressed to improve precision management decisions. Recently, the Veris $\mathrm{pH}$ Manager ${ }^{\mathrm{TM}}$, a sensor for high-resolution mapping of soil $\mathrm{pH}$ at the field scale, has been made commercially available in the US. While driving over the field, soil $\mathrm{pH}$ is measured on-the-go directly within the soil by ion selective antimony electrodes. The aim of this study was to evaluate the Veris $\mathrm{pH}$ Manager ${ }^{\mathrm{TM}}$ under farming conditions in Germany. Sensor readings were compared with data obtained by standard protocols of soil pH assessment. Experiments took place under different scenarios: (a) controlled tests in the lab, (b) semicontrolled test on transects in a stop-and-go mode, and (c) tests under practical conditions in the field with the sensor working in its typical on-the-go mode. Accuracy issues, problems, options, and potential benefits of the Veris $\mathrm{pH}$ Manager $^{\mathrm{TM}}$ were addressed. The tests demonstrated a high degree of linearity between standard laboratory values and sensor readings. Under practical conditions in the field (scenario c), the measure of fit $\left(\mathrm{r}^{2}\right)$ for the regression between the on-the-go measurements and the reference data was $0.71,0.63$, and 0.84 , respectively. Field-specific calibration was necessary to reduce systematic errors. Accuracy of the on-the-go maps was considerably higher compared with the $\mathrm{pH}$ maps obtained by following the standard protocols, and the error in calculating lime requirements was reduced by about one half. However, the system showed some weaknesses due to blockage by residual straw and weed roots. If these problems were
\end{abstract}


solved, the on-the-go sensor investigated here could be an efficient alternative to standard sampling protocols as a basis for liming in Germany.

Keywords: precision agriculture; soil sensors; digital soil mapping; soil sampling; pH; antimony electrode; Veris $\mathrm{pH}$ Manager ${ }^{\mathrm{TM}}$

\section{Introduction}

The $\mathrm{pH}$ value is the negative logarithm of the molar concentration of protons (or hydronium-ions) in a solution:

$$
p H=-\log \left(a_{H^{+}}\right)\left\lfloor\mathrm{mol} \cdot \mathrm{L}^{-1}\right\rfloor
$$

As a measure of soil acidity or alkalinity, soil $\mathrm{pH}$ constitutes one of the most important chemical soil parameters [1]. Generally, soil $\mathrm{pH}$ values outside the range of 5.5 to 6.5 are considered as nonoptimum because they can have negative impacts on nutrient availability [2,3], soil structure [4], soil organisms [5], and can make plants more sensitive to diseases [6]. Due to uptake by plants and natural leaching of alkaline soil compounds, acidification is common among soils in temperate climates. Fewer soils, like soils on limestone or on glacial till, have high $\mathrm{pH}$ values. The regulation of soil $\mathrm{pH}$ by applying alkaline or acid fertilizers can limit effects of extreme acidic or alkaline soil conditions, which in turn improves crop production and resource efficiency [7]. In a global view, soil $\mathrm{pH}$ regulation becomes a vital strategy within a radically changing world, where globally average crop yields must be increased by $60 \%$ to $120 \%$ until 2050 to meet the needs of the human population and dietary habits [8].

It is well known that $\mathrm{pH}$ values, and consequently liming requirements, can vary within an agricultural field. Thus, it may be profitable to apply lime according to the spatial variation of soil $\mathrm{pH}$ within the fields using precision agriculture (PA) technologies [9-11]. This assumes that accurate maps of soil $\mathrm{pH}$ are used as inputs. The quality of $\mathrm{pH}$ maps is predominantly influenced by sampling density, while other factors such as measurement errors are less important [12].

It turns out that sufficient sampling density can be relatively high. Mueller et al. analyzed different sampling resolutions (30-100 m) and concluded that grid sampling at $100 \mathrm{~m}$ sample distance is grossly inadequate to resolve within-field variability of soil $\mathrm{pH}$ [13]. Likewise, Brouder et al. found that sample distances greater than $100 \mathrm{~m}$ cannot reveal the spatial pattern of soil $\mathrm{pH}$ and are too uninformative for map generation [14]. Nevertheless, current standard sampling strategies do not allow for a density beyond 1 sample ha ${ }^{-1}$ because it involves manual soil sampling and laboratory analysis, which is costly and time consuming $[15,16]$.

Standard and alternative sampling procedures are summarized in Figure 1. Area (or cell) sampling on a regular grid with bulking of several subsamples into one composite sample (Figure 1A) is the most common strategy and is often recommended by authorities like the German Advisory Board for Agricultural Analytics, VDLUFA [17], or the British Ministry of Agriculture, Fisheries and Food [18]. According to the guidelines in [17], fields should be subdivided into regular parcels of 3 to 5 ha. Within these parcels, 15 to 20 subsamples should form one composite sample. The subsamples should 
be taken evenly distributed on a diagonal or Z-shaped track (Figure 1A-a). Bulking increases the sampling support and improves the precision when average values are required [19]. However, grid area composite sampling may not reveal spatial variation very well because soil properties are attributed to arbitrarily chosen zones that may not coincide with the spatial pattern observed in the field.

Figure 1. Sketch of standard and alternative sampling strategies for soil $\mathrm{pH}$ mapping (details are given in the text).

\section{A) \\ Grid sampling with bulking}

a) Area composite

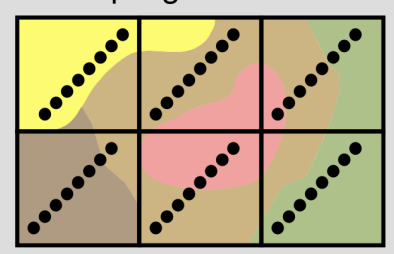

b) "Point" composite sampling
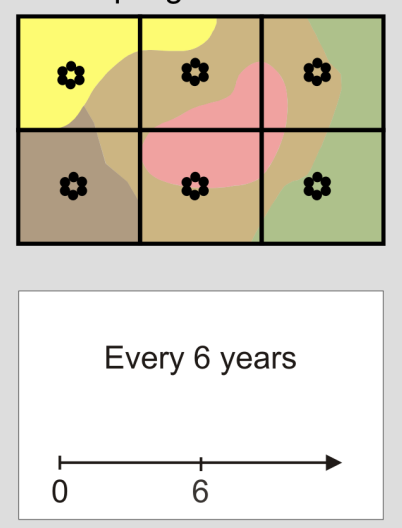

B) Targeted sampling with bulking

a) Area composite sampling

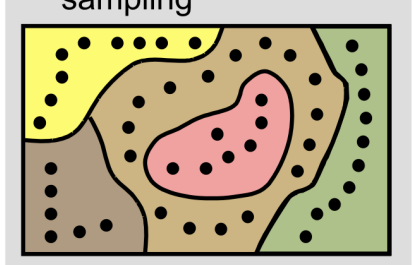

b) "Point" composite sampling

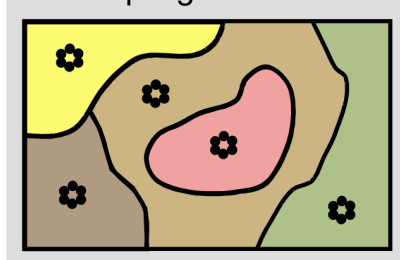

Every 6 years

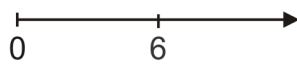

C)

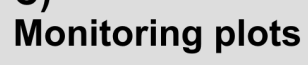

Frequent sampling at a few representative monitoring plots

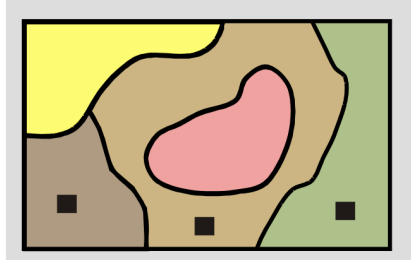

Every year

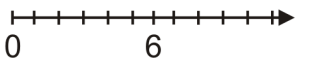

D) Spatially dense
sampling

a) Sample preparation in the field

b) Accelarated analysis in the lab

c) Online analysis

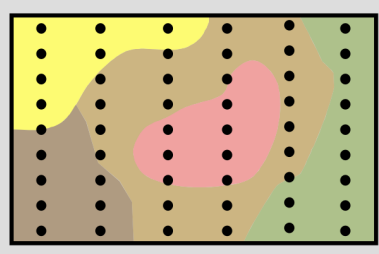

Every 6 years or more often

0

Point composite sampling on a regular grid (Figure 1A-b) is based on the bulking of samples taken within a few meters around a (regular) grid point [17,20]. Contrary to grid area composite sampling, this kind of sampling allows for interpolation, which can generate smooth surfaces for soil properties, like $\mathrm{pH}$. However, care should be taken because interpolation is only sensible when spatial dependency between the $\mathrm{pH}$ values is evident. Thus, VDLUFA suggests using grid point composite sampling only with sampling densities less than 3 ha [17].

Targeted (directed or zone) sampling (Figure 1B) takes into account previous knowledge about the distribution of the soil property of interest within a field [20-22]. This information may come from preceding intensive soil surveys or other auxiliary data (e.g., aerial images, terrain models). Based on these ancillary data, the field is subdivided into irregular shaped zones, which are addressed either by area composite (Figure 1B-a) or by point composite sampling (Figure 1B-b). Targeted sampling relies on the correlation (coincidence) between the ancillary data and the soil parameter under consideration (the $\mathrm{pH}$ distribution in our case). This is not always easy to establish [23]. Thus, it cannot be said that targeted sampling is generally better than grid sampling [21]. 
The use of monitoring plots makes even stronger assumptions about the representativeness of sampling locations (Figure 1C). It is assumed that a small plot of a few square meters is representative for the dominant soil types within the field and that the rest of the field will respond similarly to the monitoring area [17,24]. Only a very few number of samples are used which allows the increase of samples over time. With monitoring plots, soil samples may be taken every year, which can reflect year-to-year variations much better than sampling every four to six years. This is the recommended temporal interval for grid or targeted sampling [17,25]. However, because monitoring plots do not provide a full indication of field variability, they are not a typical method to derive application maps for liming. Farmers and their advisors still prefer grid or targeted sampling.

With the advent of PA technologies, the demand for high-resolution soil maps becomes much more evident [26] and spatially densed soil sampling becomes sensible (Figure 1D). Thus, efforts have been made to increase sampling density by introducing new technologies. Lütticken reports an automated soil sampling system that carries out preconditioning of soil samples in the field to accelerate conventional laboratory analysis [27]. Another approach to accelerate soil analysis and to reduce cost is to replace standard laboratory methods with new sensors and methods for data processing [26]. In particular, spectrophotometric sensors together with Partial Least-Squares regression offer potentials for high-throughput analysis of soil samples [26,28]. However, these methods still need soil samples brought to the lab and require sample preparation for analysis. The ultimate solution, therefore, would be to conduct soil analysis within the field in real-time.

Any results from new methods for online analyses of soil $\mathrm{pH}$ within the field must be comparable with results from standard methods. The standard methods require a number of soil cores to be taken, bulked, and mixed. Then, an aliquot is taken for further analysis in the lab, where it is preconditioned by air drying and sieving. After adding a certain proportion of liquid (distilled water or $\mathrm{CaCl}_{2}$ solution) and soaking or shaking, the $\mathrm{pH}$ is measured by an ion-selective glass electrode [29]. Sampling procedures, liquids, and liquid ratios may vary between and within countries, but the glass electrode is always used as the standard for $\mathrm{pH}$ measurements in soil solutions.

In general, the potentiometric determination of the $\mathrm{pH}$ value is defined as follows [30]:

$$
p H(X)=p H(S)+\frac{E(S)-E(X)}{(R \cdot T / F) \ln 10}
$$

where $\mathrm{R}$ denotes the gas constant, $\mathrm{T}$ the thermodynamic temperature, and $\mathrm{F}$ the Faraday constant. $\mathrm{E}(\mathrm{S})$ and $\mathrm{E}(\mathrm{X})$ describe the electrode potential of a $\mathrm{pH}$ cell containing a standard solution with known $\mathrm{pH}$ value, $\mathrm{pH}(\mathrm{S})$, and a solution with unknown $\mathrm{pH}$ value, $\mathrm{pH}(\mathrm{X})$. The measuring principle is based on the electrochemical reaction that takes place on the surface of the sensing electrode plunged into the solution of unknown $\mathrm{pH}$. This reaction generates a potential at the sensor electrode, $\mathrm{E}(\mathrm{X})$, which is proportional to the logarithm of the hydrogen ion $\left(\mathrm{H}^{+}\right)$activity in the unknown solution, as described by the Nernst equation [31,32]. While the potential $\mathrm{E}(\mathrm{S})$ at the reference electrode is held constant, the $\mathrm{pH}$ value is derived from the difference $\mathrm{E}(\mathrm{S})-\mathrm{E}(\mathrm{X})$.

The glass electrode is the most important electrochemical sensor [31], and it is the standard for soil $\mathrm{pH}$ determination in the laboratory $[7,29,33]$. It uses a thin membrane of sodium silicate glass as the sensing electrode [31]. During the production of the glass membrane, alumina, sodium, and other substances are added to achieve high $\mathrm{H}^{+}$selectivity [31,32]. Thus, these types of electrodes are called 
ion-selective electrodes (ISE). Because of the fragility of the glass membrane, mechanical strains should be avoided, and it is not advisable to use glass electrodes in harsh environments.

To increase sampling density for $\mathrm{pH}$ mapping while keeping costs low, efforts have been made to measure soil $\mathrm{pH}$ on-the-go while travelling across the field. Adamchuk et al. [33] developed an automated sampling system for measuring soil $\mathrm{pH}$ electrochemically based on earlier works [34]. This method takes soil samples automatically from a depth of approximately $10 \mathrm{~cm}$ while the device is moving over the field. The soil material is then brought into direct contact with two flat surface combination glass electrodes. The $\mathrm{pH}$ value is recorded after stabilization of the electrode output together with GPS coordinates. A subsequent linear regression with reference $\mathrm{pH}$ values showed $\mathrm{r}^{2}$ of 0.83 and a standard error of prediction of 0.45 . Later on, glass electrodes were replaced by antimony electrodes because of the rapid wear and leaching of the glass membrane [35].

Viscarra Rossel et al. reported about a soil $\mathrm{pH}$ and lime requirement sensing system that consisted of a soil sampler, a sieving unit and an analytical unit [36]. Sieving ensures that only soil material with a particle size of $2 \mathrm{~mm}$ or less is passed to the analytical unit, where the soil material is mixed with different extraction solutions $\left(\mathrm{H}_{2} \mathrm{O}, \mathrm{CaCl}_{2}\right.$, Mehlich lime requirement buffer) and analyzed by an ion selective field effect transistor (ISFET). Although a number of problems have yet to be addressed, the initial results are promising. Measurements taken on one field showed average deviations from reference values of $0.37 \mathrm{pH}\left(\mathrm{CaCl}_{2}\right)$ and $0.68 \mathrm{pH}\left(\mathrm{H}_{2} \mathrm{O}\right)$. Sethuramasamyraja et al. evaluated an Agitated Soil Measurement (ASM) method for integrated on-the-go mapping of soil $\mathrm{pH}, \mathrm{K}$ and $\mathrm{N}$ using ISE [37]. They investigated simultaneous placement of different ISEs into a stirred (agitated) 1:1 soil-water suspension made with deionized water, while washing the electrodes with tap water. They reported high correlations with laboratory reference measurements.

Up to now, only one on-the-go sensing system for soil $\mathrm{pH}$ has been commercialized. The system is based on the system developed by Adamchuk et al. [33], and was combined with the Veris soil apparent electrical conductivity (ECa) sensor [38]. The so-called $\mathrm{pH}$ Manager is now marketed by Veris Technologies (Salina, USA) as a part of the mobile sensor platform Veris MSP. In the US, Adamchuk et al. compared the $\mathrm{pH}$ maps of the Veris MSP (pH Manager) with maps derived from standard grid sampling on eight fields [39]. They concluded that a field specific calibration was necessary to improve the results obtained with standard grid sampling. In another study [40], the Veris MSP employing antimony ISEs was used on two fields. It was shown that maps derived from on-the-go measurements were more accurate in delineating acidic soil areas than corresponding maps derived from grid sampling or field average methods.

Currently, sensor-based soil $\mathrm{pH}$ mapping has already been adopted by agricultural service providers and farmers in the United States (more than 130 units have been sold in the US [41]). However, in Germany and in other European countries, this technique is new. To analyze the possibilities of soil $\mathrm{pH}$ on-the-go mapping in Germany, we evaluated the Veris Multi Sensor Platform (MSP) along with its soil $\mathrm{pH}$ unit (Soil $\mathrm{pH}$ Manager). The main questions addressed in this study were the following:

- How accurate is the sensor? Is its output related to standard determination of soil $\mathrm{pH}$ by $\mathrm{CaCl}_{2}$ extraction in Germany under laboratory and field conditions?

- Is there a need to calibrate the sensor $\mathrm{pH}$ values to obtain a correlation with lab $\mathrm{pH}$ values?

- Can soil electrical conductivity, measured along with $\mathrm{pH}$, help to improve calibration? 
- What problems may arise when using the Veris Soil $\mathrm{pH}$ Manager ${ }^{\mathrm{TM}}$ under German soil and farming conditions, and how can we improve the system?

- What is the accuracy of the map obtained from on-the-go measurements compared with maps generated by standard sampling and laboratory analysis, and what are the consequences for lime requirement rates?

\section{Experimental Section}

\subsection{The Soil pH Manager ${ }^{T M}$}

The Soil $\mathrm{pH}$ Manager ${ }^{\mathrm{TM}}$ of Veris Technologies is a real-time sensor for soil $\mathrm{pH}$ mapping. It automatically collects soil samples and measures soil $\mathrm{pH}$ from direct contact to the soil material on-the-go. It consists of three main components: a hydraulic soil sampling system, a $\mathrm{pH}$ electrode measurement system, and a water wash system (Figure 2). While driving, the soil sampler shoe (1) is lowered into the soil via a hydraulic cylinder on a parallel linkage (2). Sampling depth and time are adjustable but typically set to $0.01 \mathrm{~m}$ and $2 \mathrm{~s}$. While in the soil, the front of the shoe cuts the soil material with a cone (3) and produces a soil core flow through the trough of the shoe. Then, the shoe is raised to bring the soil sample into direct contact with two antimony $\mathrm{pH}$ electrodes (5). Concurrently, the shoe is passing a scraper (4) to clean the front. The up and downward movement of the shoe is controlled by a proximity sensor. The measurement is done with nontreated, naturally moist soil material, so no solution is added to the soil before being brought into contact with the electrodes. The obtained $\mathrm{pH}$ value is then computed from the averaged voltage outputs of the two electrodes. Conversion of voltage to $\mathrm{pH}$ units is achieved by a calibration routine that involves measurement of two standard solutions with known $\mathrm{pH}$ values of 4 and 7.

Figure 2. Schematic of the Veris Multi Sensor Platform (MSP) including the Soil $\mathrm{pH}$ Manager and the Soil Electrical Conductivity Surveyor. Numbers are explained in the text.

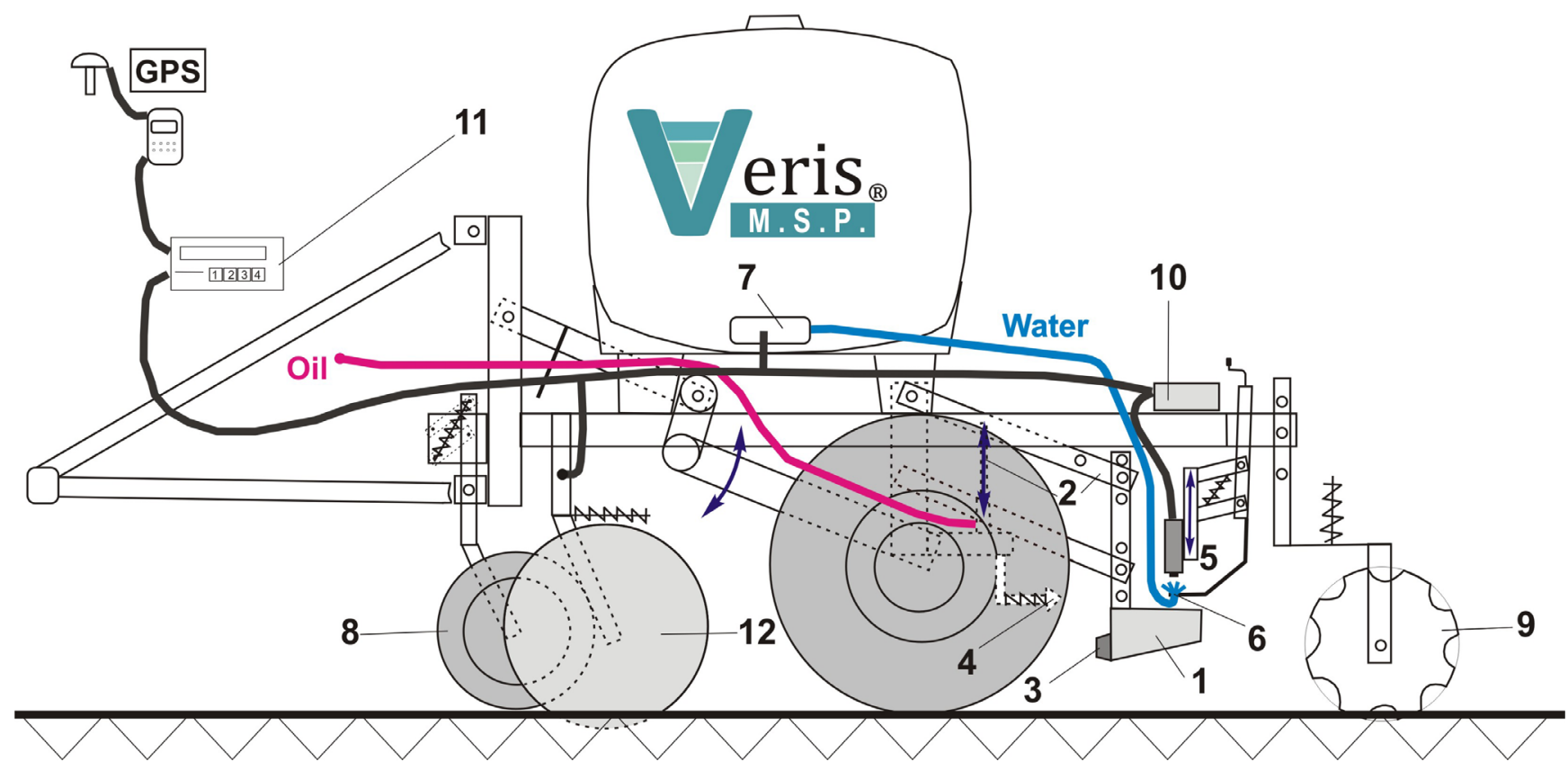


Measurement time depends on the electrode response and ranges between 7 and $25 \mathrm{~s}$. After the $\mathrm{pH}$ measurement has finished, the shoe is lowered into the soil again and the analyzed soil sample is discharged by the new soil material flowing through the cone. Simultaneously, the electrodes are rinsed by two wash nozzles (6) installed at each side of the electrode holder. The water is stored in a 359 L tank with two electric water pumps (7). Row cleaners (8) remove crop residue in front of the sampler shoe and furrow closers (9) are available to fill the furrow produced by the shoe. The sampling process and the $\mathrm{pH}$ electrode signals are managed by an external controller (10), which sends the data to a user interaction device (11). It is possible to set the controller to manual state, which allows manual operation of the sampler and the water wash system. During field operation, differential GPS coordinates are recorded at the moment the sampler shoe is pulled out of the soil.

The Soil pH Manager ${ }^{\mathrm{TM}}$ is a module of the Veris Mobile Sensor Platform (MSP), which consists of a soil electrical conductivity/resistivity device as the base unit (12). The apparent electrical resistivity $(\Omega \cdot \mathrm{m})$ is measured by the four-point method and converted to apparent electrical conductivity (ECa in $\mathrm{mS} \cdot \mathrm{m}^{-1}$ ). Six EC coulter electrodes (rolling electrodes) enable the system to map soil ECa data continuously from two soil depths. The effective depth (depth above which $50 \%$ of signal contribution effect is derived) for the narrow electrodes is $0.12 \mathrm{~m}\left(\mathrm{ECa}_{\text {shallow }}\right)$, and $0.37 \mathrm{~m}$ for the wide electrodes $\left(\mathrm{ECa}_{\text {deep }}\right)$ (see [42] for further details).

\subsection{Electrochemical pH Measurement Using Antimony Electrodes}

The soil pH sensor uses antimony electrodes (Figure 3) instead of glass electrodes because of their greater robustness [35]. The assembly of the antimony electrode is very similar to the glass electrode but consists of a slab of antimony as the sensor electrode. On its surface, an adsorbed film of mainly antimony trioxides $\left(\mathrm{Sb}_{2} \mathrm{O}_{3}\right)$ is present, which is formed by air oxidation. The potential of the sensor electrode is the consequence of a reaction of this adsorbed film with $\mathrm{H}^{+}$ions in the solution [43]:

$$
\mathrm{Sb}_{2} \mathrm{O}_{3}+6 \mathrm{H}^{+}+6 e=2 \mathrm{Sb}+3 \mathrm{H}_{2} \mathrm{O}
$$

As can be derived from Equation (2), the resulting potential, $\mathrm{E}_{\mathrm{e}}$, changes linearly with $\mathrm{pH}$ [43]:

$$
E_{e}=E_{e}(0)-\frac{R \cdot T \cdot \ln 10}{F} p H(X)
$$

Despite the obvious similarities, there are some marked differences of antimony electrodes when compared with glass electrodes. Generally, the initial electrode potential $\mathrm{E}_{\mathrm{e}}(0)$ is lower than glass electrodes. Furthermore, the resulting electrode potential, $\mathrm{E}_{\mathrm{e}}$, is influenced by several oxidizing and reducing substances that affect the $\mathrm{Sb}$ species at the electrode surface, such as dissolved oxygen, carbon dioxide or hydroxyacids [44]. Cations replaceable by antimony cause a disturbance when present in the solution and phosphate is known to have an effect on the potential [45]. Additionally, the potential of the electrode can also be altered by stirring the solution [43]. Thus, the potentials of individual antimony electrodes are deemed to be poorly reproducible, and the observed response characteristics may deviate from theoretical assumptions [43]. However, several studies found good agreement between antimony electrodes and glass electrodes for $\mathrm{pH}$ measurement in soil solutions $[44,46]$. The main advantage of the antimony electrode is its robustness. Mechanical cleaning of the electrode's surface is considered as uncritical [47]. 
Figure 3. The antimony electrode used with the Soil pH Manager (length: $120 \mathrm{~mm}$, diameter: $12 \mathrm{~mm}$ ).

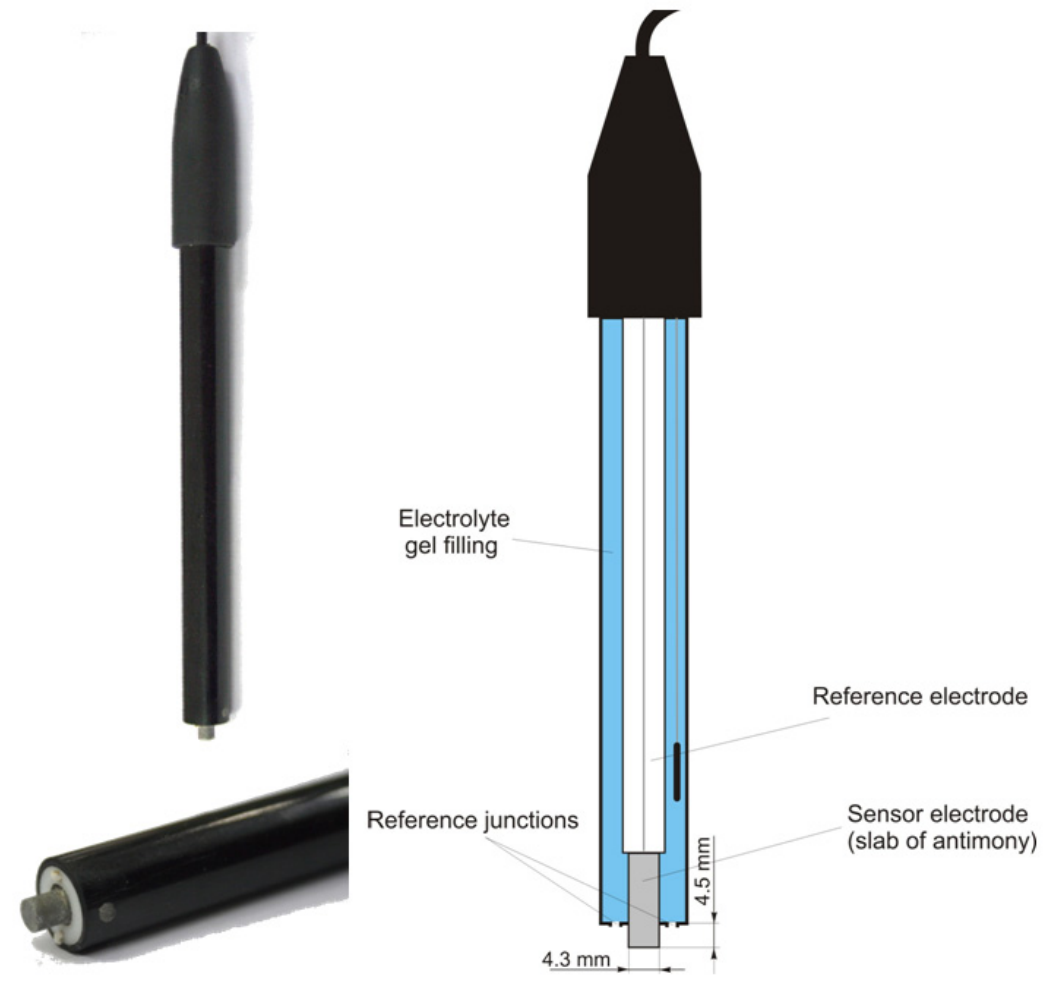

For accurate measurements, it is essential to calibrate the antimony electrode with several buffer solutions of known $\mathrm{pH}$ value [43]. Therefore, we calibrated the Veris antimony electrodes with a two-point calibration using standard buffer solutions of $\mathrm{pH} 4$ and 7 at the beginning of each experiment. We later refer to this as the basic calibration. At the beginning of the calibration, the electrodes were inserted into the buffer solution and the solution was gently stirred for $30 \mathrm{~s}$ to achieve a steady state. Both electrodes were simultaneously calibrated using the protocol of the Veris instrument.

\subsection{Laboratory Reference Measurements}

All soil samples were analyzed for soil $\mathrm{pH}$ following the German standard protocol for the determination of lime requirements [48]. Soil samples were oven dried $\left(40{ }^{\circ} \mathrm{C}\right)$ and sieved $(2 \mathrm{~mm})$. Then, $10 \mathrm{~g}$ of soil material was mixed with $25 \mathrm{~mL} 0.01 \mathrm{M} \mathrm{CaCl}_{2}$ solution. The soil suspension was shaken for $1 \mathrm{~h}$ and stored without agitation for $1 \mathrm{~h}$. Before the $\mathrm{pH}$ measurement, the soil suspension was shaken again. The $\mathrm{pH}$ measurement was conducted using a glass electrode, which was calibrated using a two-point buffer standard ( $\mathrm{pH} 4$ and 7). The electrode reading was considered stable when no change of more than $0.02 \mathrm{pH}$ occurred within $5 \mathrm{~s}$.

Soil $\mathrm{pH}\left(\mathrm{CaCl}_{2}\right)$ is the most important parameter for calculation lime requirements in Germany [48]. The use of $\mathrm{CaCl}_{2}$ solution for $\mathrm{pH}$ determination is preferred in plant nutrition and soil science because it minimizes the dilution and paste effects observed with $\mathrm{pH}$ measurements in pure soil/water solutions [29]. However, in addition to the activity of solute $\mathrm{H}^{+}$, a small amount of reserve $\mathrm{H}^{+}$acidity is measured due to cation exchange by $\mathrm{Ca}^{2+}$. 


\subsection{Experimental Design}

For adoption of a new system, it is important to know what quality it provides against an established standard. A deviation of less than $\pm 0.05 \mathrm{pH}$ units would be the ultimate goal because such an error will not cause any changes when determining lime requirement (see Section 2.5). Experiments with the soil $\mathrm{pH}$ sensor were therefore conducted under different conditions: (a) controlled conditions in the lab, (b) semicontrolled conditions moving the sensor in a stop-and-go mode along a transect, and (c) practical conditions working in the regular on-the-go mode.

Experiments (a) and (b) mainly addressed issues related to the differences between measurements with the standard glass electrode in a soil solution and the antimony electrode of the $\mathrm{pH}$ Manager in field moist soil. Tests under practical conditions (c) addressed problems invoked by on-the-go field operation, the advantages of the soil $\mathrm{pH}$ sensor compared with conventional mapping, and its utility to derive application maps for liming.

Outdoor measurements were conducted in three fields (A, B, and C). All fields were located in Northeastern Germany. Table 1 comprises some field properties. In Northeastern Germany, soils were formed on glacial and periglacial sediments. Most topsoils are acid and sandy. However, $\mathrm{pH}$ values can vary due to the influence of carbonates on soils formed on glacial till.

Table 1. Field conditions.

\begin{tabular}{lcccc}
\hline & Soil texture & $\begin{array}{c}\text { Soil } \mathbf{~ p H ~ r a n g e} \\
\mathbf{p H}\left(\mathbf{C a C l}_{\mathbf{2}}\right)\end{array}$ & Geology & $\begin{array}{c}\text { Date of } \\
\text { measurement }\end{array}$ \\
\hline Field A & Sand/Silty sand & $3.83-6.75$ & Fluvial deposits & 23.03 .2010 \\
Field B & Silty sand & $5.00-7.00$ & Glaciofluvial deposits (outwash) & 15.04 .2010 \\
Field C & Loam/silty sand & $4.0-7.5$ & Glacial deposits & 05.08 .2010 \\
\hline
\end{tabular}

Experiments under Controlled Conditions

The first experiment tested the $\mathrm{pH}$ measurement system of the soil $\mathrm{pH}$ sensor under laboratory conditions. Four preselected soil samples (400 g) that spanned the $\mathrm{pH}$ range between 4 and 7 were measured repeatedly with direct contact of the two antimony electrodes using the Veris data logger as the measurement instrument. To assure homogeneity and the same level of moisture for each sample, soil material was grounded, sieved $(2 \mathrm{~mm})$ and oven dried $\left(40{ }^{\circ} \mathrm{C}\right)$ before $10 \%$ deionized water was added to the soil sample. Before each measurement, the electrodes were washed for $10 \mathrm{~s}$ with deionized water and then were gently pressed into the soil material until a complete coverage of the tip of the electrode was guaranteed (approx. $10 \mathrm{~mm}$ ). In the first test, the electrode's response time was analyzed by taking sensor readings after 5, 10 and $20 \mathrm{~s}$. Measurements were then compared with laboratory reference measurements [48]. All measurements were repeated 10 times. In a second test, the antimony electrode was analyzed for dependence of subsequent measurements on previous measurements. To reveal possible "memory effects" of antimony electrodes two soil samples of pH 4 and 7 were measured in an alternating sequence. 
Experiments under Semicontrolled Conditions

In this experiment, the soil $\mathrm{pH}$ sensor was brought outside (field $\mathrm{C}$ ) and operated in the manual mode. On two transects (330 and $440 \mathrm{~m}$ ), 55 measurements were taken and measured with antimony and glass electrodes. While moving the system with a tractor, the soil sampler shoe was lowered manually into the soil and raised again after a soil core flow through the trough had been developed. The tractor was stopped, and the $\mathrm{pH}$ readings were noted after the electrodes had been pressed against the soil material for $15 \mathrm{~s}$. After that, the electrodes were washed with deionized water using the two wash nozzles and were dried with a piece of paper. Soil material within the trough was collected for reference measurement with glass electrodes in the lab. Then, the tractor pulled the sensor platform to the next measurement point while the shoe was lowered into the soil. At the start of each transect and in the middle of transect two, both electrodes were calibrated using the basic calibration procedure described above. This was done in order to account for possible temperature drift and other ambient influences.

Experiments under Practical Conditions

Field tests were conducted in fields A, B, and C. Before each field measurement, the electrodes were calibrated as described above. Sampling and measuring was conducted automatically in the typical on-the-go mode and electrodes were washed using tap water $\left(7.6 \mathrm{pH}\right.$ and $\left.1,060 \mu \mathrm{m} \mathrm{cm}^{-1}\right)$. While sampling, soil ECa measurements were recorded continuously along the track. Soil samples were collected one day after each field was measured. These samples were taken from the soil material remaining in the furrows caused by the soil sampler. The sampling and measurement positions were located by GPS using Trimble AgGPS with Omnistar differential correction signal ( $\pm 1 \mathrm{~m}$ accuracy). Samples were analyzed for soil $\mathrm{pH}$ in the laboratory by the standard method described above. The lab values were used for accuracy assessment and field-specific calibration. This was done by linear regression analysis (see Section 2.6). The squared correlation coefficient $r^{2}$ was used to qualify the random error, while the intercept and the slope of the regression model were indicators of systematic errors and electrode sensitivities, respectively. Additionally, the mean absolute errors (MA) and the mean error (ME) were calculated to summarize the magnitude of the errors. The linear regression models were additionally used for field-specific calibrations in order to transform Veris on-the-go field measurements into $\mathrm{pH}\left(\mathrm{CaCl}_{2}\right)$. Establishing a relationship between on-the-go $\mathrm{pH}$ and $\mathrm{pH}\left(\mathrm{CaCl}_{2}\right)$ is highly relevant because $\mathrm{pH}\left(\mathrm{CaCl}_{2}\right)$ values are used as the main input for calculating lime requirements (see next section).

\subsection{Benefits of the on-The-Go Approach Compared with Standard Protocols}

\section{Comparison of Mapping Strategies}

To evaluate the potential of on-the-go mapping quantitatively, two maps employing different standard sampling strategies were compared with on-the-go measurements from field A. Therefore, soil was collected at 55 locations spatially separated from the furrows formed by the sampler of the Veris pH Manager. These samples will be referred to as standard samples. Each standard sample was composed of 16 auger cores at a sampling depth of $0.25 \mathrm{~m}$ and distributed randomly within a 
circle $1 \mathrm{~m}$ in diameter. Sample locations were irregular distributed over the field. All standard samples were analyzed for soil $\mathrm{pH}$ in the laboratory.

The first standard map ( $\operatorname{map}_{\mathrm{WF}}$ ) simulated the results of a whole field sampling strategy. Nine standard soil samples were randomly chosen to cover the range of $\mathrm{pH}$ values and to achieve a regular distribution of locations within the field. The $\mathrm{pH}$ values of these samples were then averaged to obtain a uniform soil $\mathrm{pH}$ value, which was attributed to the entire field area to form the first standard map.

The second standard map ( $\operatorname{map}_{\mathrm{AC}}$ ) simulated the results of an area composite sampling strategy. For this purpose, the field was equally divided into three zones of approximately 1 ha. In each zone, three standard soil samples were averaged, and the averaged value was attributed to that zone. For the

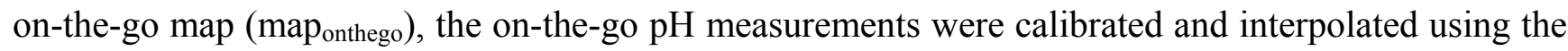
procedures below. The remaining 46 standard samples were used for validation.

\section{Consequences for Liming}

Liming needs were computed using German guidelines for fertilization (Table 2, [49]). This algorithm requires $\mathrm{pH}\left(\mathrm{CaCl}_{2}\right)$, soil texture and soil organic matter content as inputs. Organic matter content in the soils of field A was below 4\% and, thus, did not induce any variation in lime recommendation. Soil textural variation was low, and was assumed to be uniform throughout the field A. The differences between the lime requirement of the maps and the lime requirement of the validation samples were then extrapolated to the entire field.

Table 2. German recommendation table for liming $\left(\mathrm{kg} \mathrm{ha}^{-1}\right)$. Excerpt from [49] showing recommendation only for soil $\mathrm{pH}$ values within the range of 4.5 to 5.5.

\begin{tabular}{llllll}
\hline Soil pH & Sand & $\begin{array}{l}\text { Weakly } \\
\text { loamy sand }\end{array}$ & $\begin{array}{l}\text { Strongly } \\
\text { loamy sand }\end{array}$ & Silty loam & $\begin{array}{l}\text { Clay } \\
\text { loam/clay }\end{array}$ \\
\hline$\ldots$ & $\ldots$ & $\ldots$ & $\ldots$ & $\ldots$ & $\ldots$ \\
4.5 & 3,000 & 5,700 & 8,700 & 11,700 & 16,000 \\
4.6 & 2,700 & 5,300 & 8,200 & 11,100 & 15,200 \\
4.7 & 2,400 & 4,900 & 7,700 & 10,500 & 14,400 \\
4.8 & 2,200 & 4,600 & 7,200 & 10,000 & 13,600 \\
4.9 & 1,900 & 4,200 & 6,700 & 9,400 & 12,800 \\
5 & 1,600 & 3,800 & 6,300 & 8,800 & 12,100 \\
5.1 & 1,300 & 3,400 & 5,800 & 8,200 & 11,300 \\
5.2 & 1,000 & 3,000 & 5,300 & 7,600 & 10,500 \\
5.3 & 700 & 2,600 & 4,900 & 7,000 & 9,800 \\
5.4 & 600 & 2,200 & 4,400 & 6,500 & 9,000 \\
5.5 & 600 & 1,900 & 3,900 & 5,900 & 8,200 \\
$\ldots$ & $\ldots$ & $\ldots$ & $\ldots$ & $\ldots$ & $\ldots$ \\
\hline
\end{tabular}

\subsection{Data Analysis}

To quantify the precision and accuracy of the soil $\mathrm{pH}$ sensor, the sensor readings $\left(\mathrm{pH}_{\text {OTG }}\right)$ were compared with their corresponding lab reference values $\left(p H_{R E F}\right)$. The relationship between $p H_{O T G}$ and $p H_{R E F}$ was then evaluated using linear regression: 


$$
p H_{\text {OTG }}=a+b \cdot p H_{R E F}+\varepsilon
$$

Here, $a$ and $b$ denote the intercept and slope of the linear model found by minimizing the error $(\varepsilon)$ between $p H_{O T G}$ and $\mathrm{pH}_{R E F}$ using the least squares approach. As shown previously [35], on-the-go $\mathrm{pH}$ values may systematically deviate from lab $\mathrm{pH}$ values from field to field. This makes a calibration necessary with field-specific calibration samples in addition to the basic calibration of the electrodes using standard $\mathrm{pH}$ buffer solutions. For field-specific calibration, 10 samples were chosen from each of the soil samples collected on fields $\mathrm{A}, \mathrm{B}$, and $\mathrm{C}$ as calibration samples $\left(\mathrm{pH}_{\mathrm{CAL}}\right)$. Selection criteria were $\mathrm{pH}$ range and regular distribution within the field. The remaining soil samples were used for validation $\left(p H_{V A L}\right)$. A linear model can be estimated from the given calibration sample values and their corresponding on-the-go measurements:

$$
p H_{\text {OTG }}=a+b \cdot p H_{C A L}+\varepsilon
$$

The inverse estimator is given by the simple linear regression of $p H_{C A L}$ on $p H_{O T G}$ [50]:

$$
p H_{C A L}=a_{C A L}+b_{C A L} \cdot p H_{\text {OTG }}
$$

The calibration parameters $a_{C A L}$ and $b_{C A L}$ are estimated and allow the linear transformation of the uncalibrated $\mathrm{pH}_{\text {ОтG }}$ values. This calibration model can be extended by including co-variables. In our case, we tested if the integration of soil ECa could improve the results of the calibration model. A much simpler calibration was proposed by [35], who suggested field-specific calibration by only shifting the $p H_{O T G}$ values. This was implemented here by using the mean difference between $p H_{O T G}$ and $\mathrm{pH}_{C A L}$ as the shifting parameter.

The quality of the calibration model was evaluated by comparing the mean absolute error (MAE) between the $\mathrm{pH}_{\text {OTG }}$ values and the $\mathrm{pH}_{\mathrm{VAL}}$ values before and after the calibration:

$$
\begin{aligned}
& M A E_{\text {raw }}=\frac{1}{n} \sum_{i=1}^{n}\left|p H_{\text {VAL }}-p H_{\text {OTGraw }}\right| \\
& M A E_{\text {cal }}=\frac{1}{n} \sum_{i=1}^{n}\left|p H_{\text {VAL }}-p H_{\text {OTGcal }}\right|
\end{aligned}
$$

Geostatistical methods were used to analyze the spatial structure and to compute spatial maps of the soil $\mathrm{pH}$ measurements. The omnidirectional experimental semivariogram $\hat{\gamma}(h)$ showed the average dissimilarity between the observations, $z(x)$, as a function of separation distance, $h$, with $n(h)$ denoting the number of squared differences of $\mathrm{pH}$ values at the locations $x_{i}$ and $x_{i}+h$ separated by the distance vector, $h[51]$ :

$$
\hat{\gamma}(h)=\frac{1}{2 n(h)} \sum_{i=1}^{n}\left(\mathrm{z}\left(\mathrm{x}_{\mathrm{i}}\right)-z\left(x_{i}+h\right)\right)^{2}
$$

We also computed directional experimental semivariograms that included the relative direction between the point pairs (i.e., only point pairs that fell into a given angular tolerance were classified within the lag classes of the experimental semivariogram). The omnidirectional experimental semivariograms were then parameterized using the spherical semivariogram model [51]. Parameters were computed from the semivariogram model as follows: The "range" quantified the distance within 
which observations were statistically dependent (autocorrelated). The "partial sill" denoted the structured variance that was explained by neighboring samples. The nugget effect enumerated the discontinuity of the semivariogram model at its origin $(h=0)$. The nugget effect was composed of the unexplained variation that could not be resolved by the given sampling resolution (microvariance) and the sample measurement error. The "nugget to sill ratio" (NSR) then expressed the percentage of the nugget effect on the total sill (nugget effect + partial sill). Soil pH maps were computed using ordinary kriging, or, if a spatial trend was present, by universal kriging [51].

\section{Results and Discussion}

\subsection{Testing the Soil Sensor under Controlled Conditions}

In the analysis of the response time of the antimony electrodes, the $\mathrm{pH}$ readings became more stable the longer the electrodes were retained within the soil (Figure 4). After $5 \mathrm{~s}$ of retention, $\mathrm{pH}$ values varied between 0.20 and 0.35 , and after $20 \mathrm{~s}$, they fluctuated within 0.10 and $0.25 \mathrm{pH}$ units. Laboratory $\mathrm{pH}$ measurements $(\mathrm{lab} \mathrm{pH})$ using the standard protocol of $\mathrm{pH}$ determination were much more precise.

Figure 4. Soil pH measurements using antimony electrodes at 5, 10 and $20 \mathrm{~s}$ time intervals compared with lab reference measurements under laboratory conditions. Points correspond to the median of 10 replicates. The whiskers of the box plots display the range of the repeated measurements. The thick lines show the corresponding lab $\mathrm{pH}$ value.

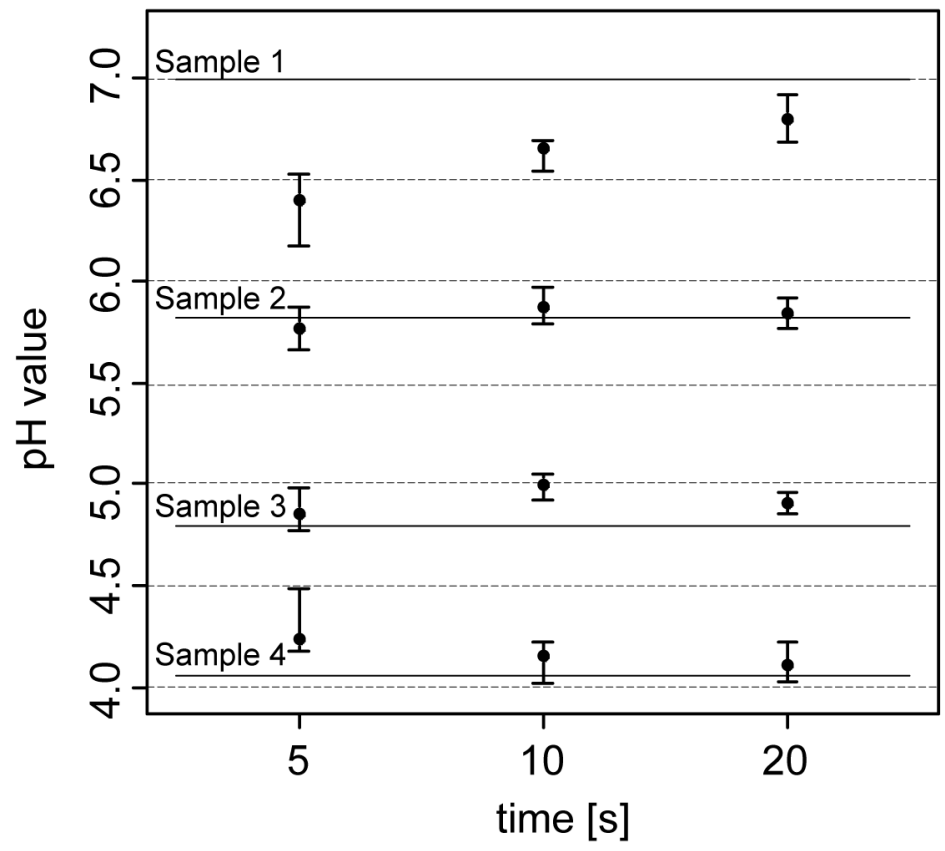

$\mathrm{Lab} \mathrm{pH}$ only varied between 0.02 and $0.07 \mathrm{pH}$ units. In terms of measurement accuracy, sensor $\mathrm{pH}$ readings differed from the lab $\mathrm{pH}$ by $0.22 \mathrm{pH}$ units $(5 \mathrm{~s})$ and $0.09 \mathrm{pH}(20 \mathrm{~s})$ units. Other studies found similar or greater differences. Conkling and Blanchar [44] compared an antimony electrode with a glass electrode in a soil-water solution and showed an average discrepancy of $0.32 \mathrm{pH}$ units, while Baghdady [46] observed a difference of only $0.07 \mathrm{pH}$ units when measuring a soil buffer solution. In our test, discrepancies between antimony and glass electrodes seemed to depend on the $\mathrm{pH}$ value. As 
the $\mathrm{pH}$ values became more extreme ( $\mathrm{pH} 4$ and 7), the antimony electrode readings showed an increasing offset compared with the lab $\mathrm{pH}$. With lower lab $\mathrm{pH}$, antimony electrode readings became higher, while they were lower with higher lab $\mathrm{pH}$. These differences were more pronounced with the $5 \mathrm{sec}$ measurements. The discrepancies can be explained by the direct contact soil measurement principle of the Veris sensor. On the contrary, the standard laboratory method requires mixing of the soil material with the $\mathrm{CaCl}_{2}$ solution. This will replace $\mathrm{H}^{+}$ions on soil particles and the analyzed soil solution will hold a higher $\mathrm{H}^{+}$activity than in field moist soil. Also, the short measurement time of the sensor has an influence on its accuracy. Measurement time was restricted to about 5-20 s during the field experiments. In the laboratory, the $\mathrm{pH}$ measurement value is taken after the electrode potential has stabilized. Antimony electrodes require several minutes to obtain a practical constant potential difference [52]. In addition, the electrode readings will be influenced by the sensor electronics and other specific properties of the antimony electrode. In particular, some studies indicated an underestimation of high soil $\mathrm{pH}$ values $[35,44]$ and an overestimation of low $\mathrm{pH}$ values by using antimony electrodes [53]. Additionally, the strong deviations of the sensor readings in soil sample A (with the high $\mathrm{pH}$ ) may have also been affected by inhomogeneities within the sample known as the 'nugget effect' or micro-variability [51]. We detected small particles of carbonate, which is typical for calcic soils in northern Europe formed on glacial till.

To analyze whether the antimony electrodes were exhibiting a memory effect, two soil samples with pH 4 and 7 were measured in sequence. In fact, a memory effect was observed, as depicted in Figure 5 (left). Depending on whether the previous sample had a lower or higher $\mathrm{pH}$, repeated $\mathrm{pH}$ readings from the proceeding sample were slowly increased or decreased, respectively. This memory effect was also evident when measuring alternately from sample to sample (Figure 5, right). In this case, the antimony electrodes were unable to capture the full range of the $\mathrm{pH}$ values. Therefore, when soil $\mathrm{pH}$ is changing rapidly, the antimony electrodes will slightly underestimate or overestimate the $\mathrm{pH}$ value depending on the previous sample.

Figure 5. Consecutive measurements with the $\mathrm{pH}$ antimony electrode 1 (black) and 2 (red) in two soil samples with different $\mathrm{pH}$ values under laboratory conditions.

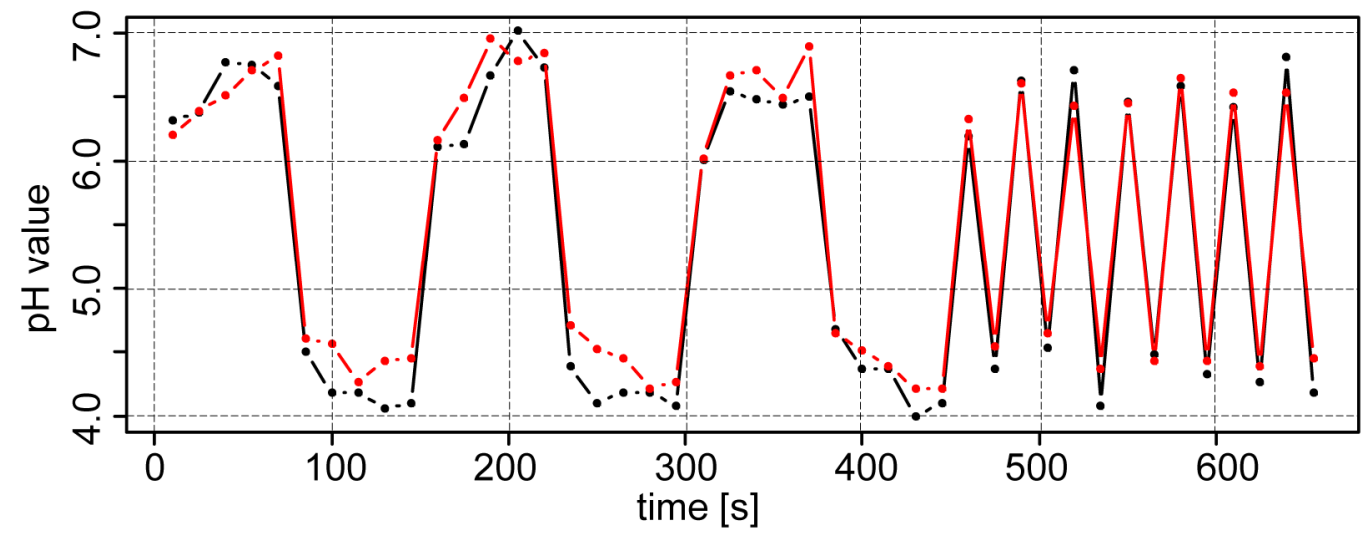




\subsection{Testing the Soil Sensor under Semicontrolled Conditions}

Figure 6 shows the results of experiments under semicontrolled conditions on a transect. Within $400 \mathrm{~m}$, high differences of soil $\mathrm{pH}$ were observed ranging from approximately 4 to $7.5 \mathrm{pH}$ (lab), highlighting the necessity of high-resolution mapping of soil $\mathrm{pH}$. With a few exceptions, the line graphs of the two antimony electrodes ran parallel to the line of the glass electrode. In general, readings of electrode \#2 were slightly lower than electrode $\# 1(-0.11 \mathrm{pH})$, which may have been due to the specific properties of each electrode. Additionally, more pronounced differences occurred in the second section of transect two after recalibration of the electrodes. Fluctuations between the two electrodes may have also been due to the heterogeneous nature of the soil in the trough.

Figure 6. Measurements on two transects with manual control of Veris MSP antimony $\mathrm{pH}$ electrodes compared with measurements with glass electrodes in the lab. Soil material was identical for both types of measurements.

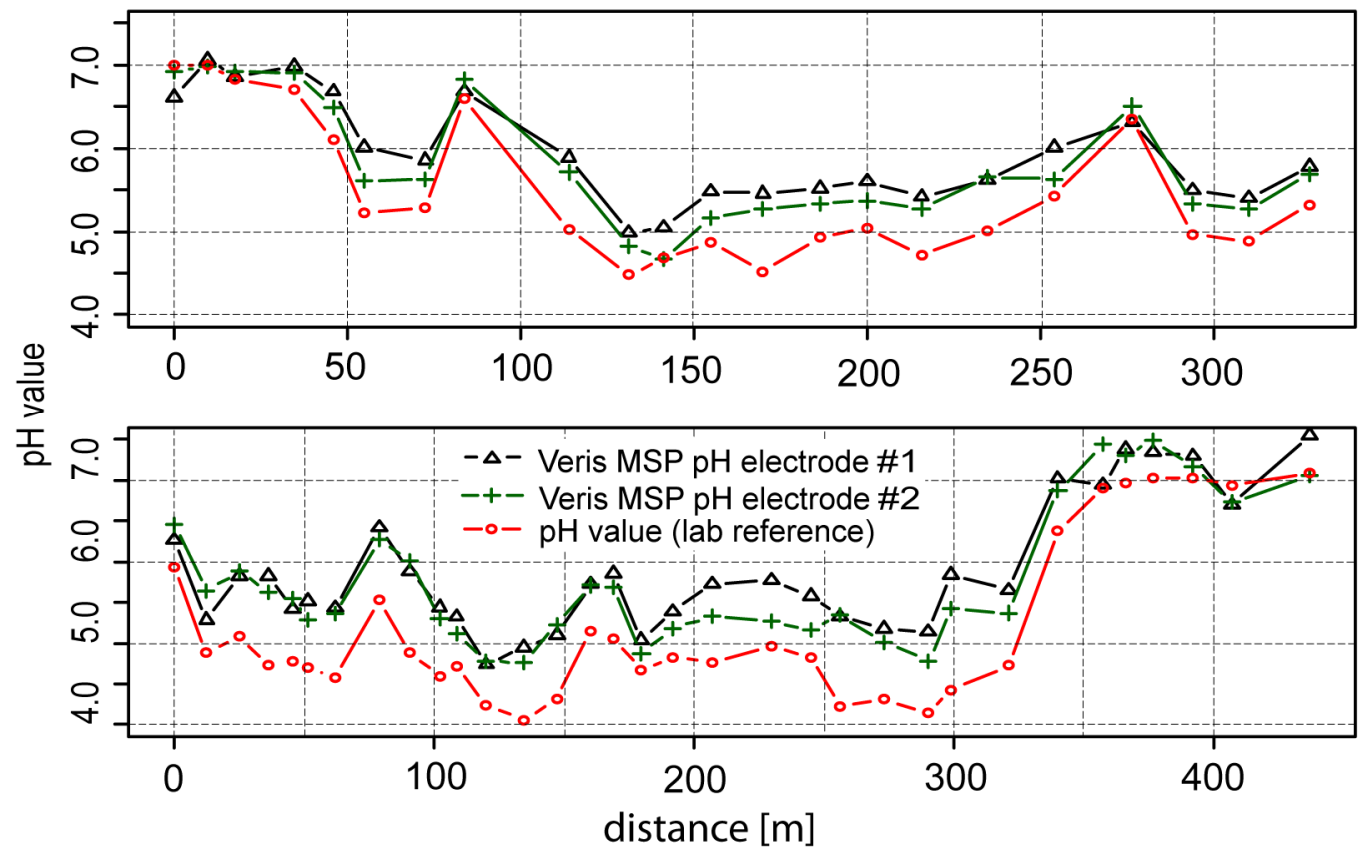

As we observed for the test under controlled conditions in the lab, the soil $\mathrm{pH}$ sensor readings were higher than $\mathrm{pH}\left(\mathrm{CaCl}_{2}\right)$ within soils with lower soil $\mathrm{pH}(-0.5 \mathrm{pH})$ values. This systematic effect was stronger in this test than in the laboratory experiment. Measurements in soils with $\mathrm{pH}$ values lower than 6 were increased by $0.65 \mathrm{pH}$ units and measurements in soils with $\mathrm{pH}$ values higher than 6 were increased by just $0.19 \mathrm{pH}$ units compared with lab $\mathrm{pH}\left(\mathrm{CaCl}_{2}\right)$.

The relation between sensor readings and lab reference is further illustrated in the scatter plot shown in Figure 7. The data was accurately described by a linear regression model using lab $\mathrm{pH}$ as the independent variable $\left(\mathrm{r}^{2}=0.92\right)$. In addition, the regression line clearly deviated from the 1:1 line, underpinning the systematic error we observed in this experiment. We explained this deviation mainly by the effect of the $\mathrm{CaCl}_{2}$ solution as an extractant even though temperature variability and characteristics of the sensor electronics might have contributed as well. For example, Conyer and Blanchar [44] analyzed the correlation between $\mathrm{pH}$ measured in a $\mathrm{CaCl}_{2}$ solution and in a $\mathrm{H}_{2} \mathrm{O} /$ soil 
dispersion using a glass electrode. The resulting linear relationship between the $\mathrm{CaCl}_{2}$ and $\mathrm{H}_{2} \mathrm{O}$ solutions took the form $\mathrm{pH}_{\mathrm{CaCl}}=1.05 \mathrm{pH}_{\mathrm{w}}-0.9$, to which our regression parameters were a close fit. Furthermore, later studies that analyzed a greater number of different soil samples revealed curvilinear relationships between $\mathrm{pH}$ measurements with $\mathrm{CaCl}_{2}$ and $\mathrm{H}_{2} \mathrm{O}$ solutions [54,55]. In our case, the scatter plot did not show nonlinear behavior. However, the intercept was approximately $1.8 \mathrm{pH}$ units and the steepness of the slope of the regression line was less than the 1:1 line in the scatter plot, leading to a high mean absolute error of $0.55 \mathrm{pH}$ units and a strong bias (mean error $=-0.53$ ). Thus, calibration was necessary to reduce the deviation between the soil $\mathrm{pH}$ sensor readings and $\mathrm{pH}\left(\mathrm{CaCl}_{2}\right)$.

Figure 7. Scatter plot of on-the-go measurements and lab $\mathrm{pH}$ values with the corresponding regression model (black line, 1) from transects shown in Figure 6. The black dotted line shows the 1:1 relationship and the red dotted line (2) is the regression model of [56].

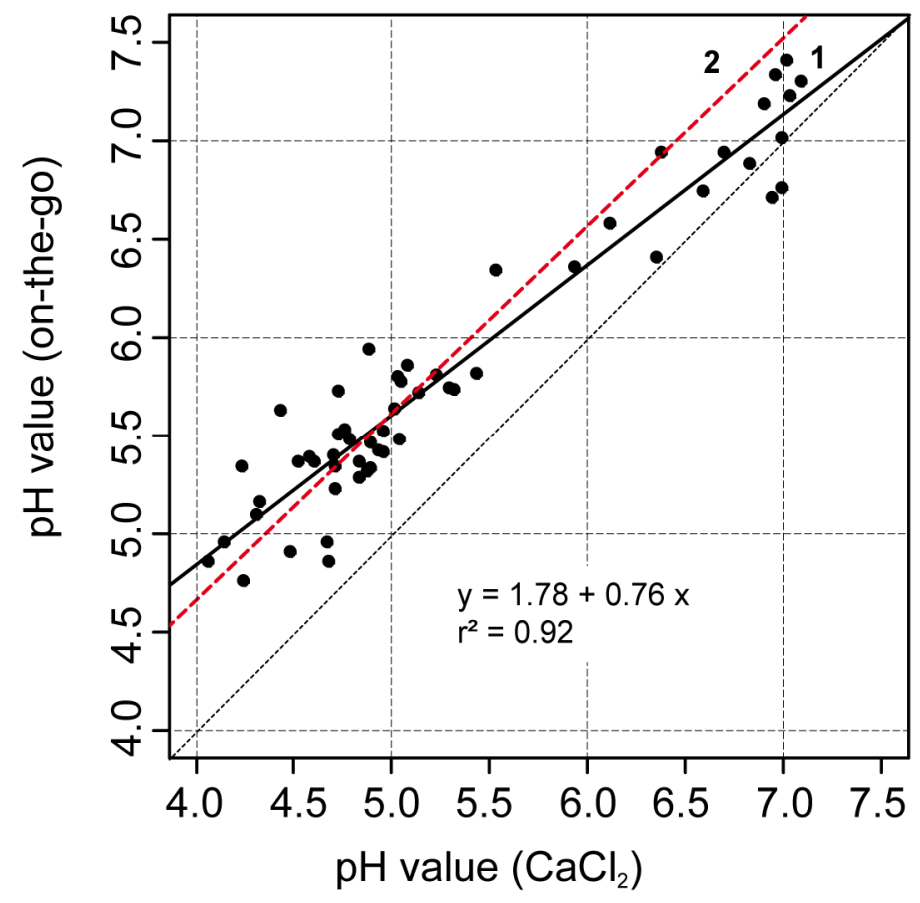

Among other factors, like sample inhomogeneity and temperature variability, field tests may be affected by spatial variations of soil water content. This might happen in at least two ways: first, increasing water content may decrease $\mathrm{H}^{+}$concentration due to a dilution effect; and second, increasing water content may raise $\mathrm{pH}$ readings, as explained by the Debye-Hückel theory. These are contrary effects and the second one requires some explanation. High concentrations of ions can lead to a deviation from the theoretical linear relationship between the concentration of ions in the solution and the electrical potential [32]. This is due to the fact that ion activity, which is the "effective concentration" in terms of the law of mass action [32], is reduced when the concentration of ions rises. With increasing concentration, ions start influencing each other and consequently reduce their mobility and reaction rates. The relationship of activity and concentration is then described by the Debye-Hückel theory [32].

In typical well-drained soils, the total concentration of ions in the water varies between 0.001 and $0.01 \mathrm{~mol} \mathrm{~L}^{-1}$ [57]. According to the Debye-Hückel theory, this range of concentrations can have 
some effect on ion activity. Therefore, Adamchuk et al. [33] analyzed the output of glass electrodes depending on soil water content. They observed a slight increase in $\mathrm{pH}$ readings when water was added to the soil, but repeated measurements with the same moisture content showed high variability. Thus, they concluded that there was no significant effect within the range of moisture contents typical for soils in the field. However, rinsing the electrodes with wash water may also indirectly affect the ion concentration. In our experiments, $0.10 \mathrm{~mL}$ of wash water was adhered at the sensor electrode on average, which is a very small amount and the effect may be neglible.

In addition, temperature variability can influence $\mathrm{pH}$ measurements in at least three ways. Firstly, potentiometric measurements are related to temperature as given by Equations 2 and 4. Second, dissociation of molecules into protons and bases is a function of temperature. Third, the electronics of the $\mathrm{pH}$ instrument can be affected. In our case, field measurements of soil temperature showed variations of less than $5 \mathrm{~K}$. Thus, soil temperature had no relevant effect on random errors but could have contributed to systematic errors. The sensitivity of the Veris $\mathrm{pH}$ instrument was not fully explored in this study and should be further analyzed in subsequent experiments.

\subsection{Testing the Soil Sensor under Field Conditions}

The use of the soil $\mathrm{pH}$ sensor on fields A, B and C resulted in high measurement densities of 91.1, 26.54 and 34.4 samples $\mathrm{ha}^{-1}$. The measurement density depended mainly on the speed and the spacing between the tracks. This represents a great improvement over manual standard sampling for site specific management practices in Germany that normally relies on 3 ha sample zones. To make full use of the on-the-go measurements, it is important to establish calibration models that convert the sensor readings into $\mathrm{pH}\left(\mathrm{CaCl}_{2}\right)$ which is the main input for calculating lime requirements. Differences of $0.1 \mathrm{pH}\left(\mathrm{CaCl}_{2}\right)$ units amount in differences in lime requirements of 300 to $400 \mathrm{~kg} \mathrm{CaO}$ per hectare on sandy soils (Table 2). In Figure 8, scatter plots depict the relationship between the on-the-go measurements and the lab $\mathrm{pH}$ values given by the soil samples collected within the furrows. On all fields, the raw, uncalibrated on-the-go measurements were linearly well correlated with the lab reference values, and $r^{2}$ values ranged between 0.63 and 0.84 . These $r^{2}$ values were slightly smaller compared with $\mathrm{r}^{2}$ values obtained by studies conducted in the United States, which were mainly between 0.73 and 0.97 [39,40,58]. A similar study conducted in Germany reported an $r^{2}$ value of about 0.62 computed over multiple fields [59].

However, a systematic deviation was observed with the on-the-go measurements and intercept values ranged between $\mathrm{pH} 2.7$ and 3.97. In this case, the intercept values were even larger and the slope values were smaller compared with the field transect test of the previous section. In addition, the raw on-the-go measurements below $4.5 \mathrm{pH}$ strongly deviated from the lab reference. This may have resulted from the relatively short measurement time of approximately 5-20 s during the field tests. To reduce this deviation, a field-specific calibration of the on-the-go measurements was conducted based on 10 calibration samples using lab reference values with inverse regression (Table 3). All resulting linear models were significant $(\mathrm{p}<0.01)$ and the field-specific calibration had a strong effect on the errors between on-the-go measurements and lab reference values. The mean absolute errors were therefore reduced for fields $\mathrm{A}, \mathrm{B}$, and $\mathrm{C}$ by $-0.79,-0.04$ and $-0.37 \mathrm{pH}$ units, respectively. The 
relatively small improvement on field B was due to the overall small variability of soil $\mathrm{pH}$ in this field. Furthermore, the bias, in terms of the mean error, was greatly reduced.

Figure 8. Scatter plots showing the relationship between on-the-go $\mathrm{pH}$ measurements and corresponding lab values on three fields. Soil samples for both analyses were taken from nearly identical locations.

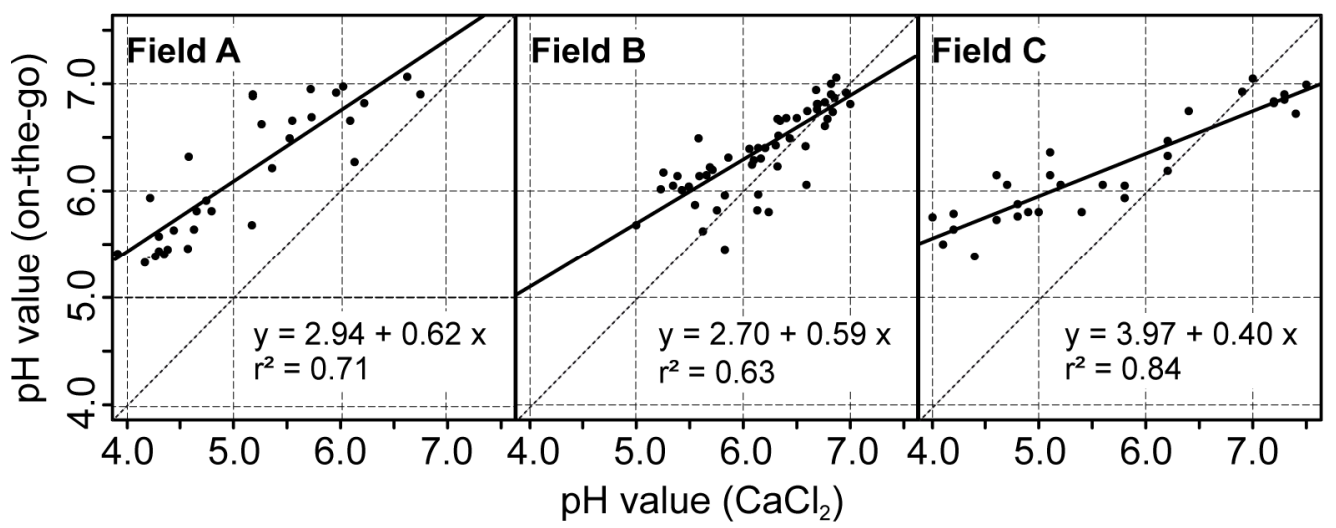

Table 3. Regression coefficients of the inverse regression between calibration $\mathrm{pH}\left(\mathrm{CaCl}_{2}\right)$ and on-the-go pH, mean absolute error (MAE), and mean error (ME) before and $\S_{\text {after }}$ calibration.

\begin{tabular}{|c|c|c|c|c|c|c|c|c|}
\hline Field & Intercept & Slope & $\begin{array}{c}\text { Mean } \\
\text { shift }\end{array}$ & p-value & MAE & ME & MAE $\mathbf{E}^{\S}$ & $\mathbf{M E} \mathbf{E}^{\S}$ \\
\hline A & -1.99 & $1.16^{* * *}$ & -0.99 & 0.0008 & 1.09 & 1.08 & $0.30 / 0.31^{\#}$ & $0.10 / 0.10^{\#}$ \\
\hline B & -2.51 & $1.36^{* * *}$ & -0.25 & 0.0006 & 0.32 & 0.20 & $0.28 / 0.28^{\#}$ & $0.04 / 0.05^{\#}$ \\
\hline $\mathrm{C}$ & $-5.89 *$ & $1.89 * * *$ & -0.47 & 0.0007 & 0.82 & 0.52 & $0.45 / 0.72^{\#}$ & $0.11 / 0.05^{\#}$ \\
\hline
\end{tabular}

Adamchuk et al. concluded that adding a constant value to the on-the-go measurements was sufficient for calibration [39]. However, in our case, this simple shifting of values was not adequate. It improved the results only for field A and B, but not for field $\mathrm{C}$. Therefore, we conclude that the use of the $\mathrm{pH}\left(\mathrm{CaCl}_{2}\right)$ method as the reference demands the two parameter linear regression model for field-specific calibration of the on-the-go measurements.

Soil ECa and on-the-go measurements corresponded reasonably well on field A and C. Best correlations, were found for field A with $\mathrm{ECa}_{\text {shallow }}(0.57)$ and for field $\mathrm{C}$ with $\mathrm{ECa}_{\text {deep }}(-0.56)$. On field $\mathrm{B}$, no significant correlation with $\mathrm{ECa}$ was found. The integration of soil ECa into the field-specific calibration model improved results only for field C. For this field, the MAE decreased from 0.45 to $0.40 \mathrm{pH}$ units using soil $\mathrm{ECa}_{\text {deep }}$. Soil variability in field $\mathrm{C}$ was strongly influenced by geology. Soil texture varied greatly and lime material was found on the hilltops. In this field, spatial changes in the reserve acidity may force $\mathrm{pH}$ values measured with $\mathrm{CaCl}_{2}$ in the lab to differ from measurements of the active acidity directly in the soil because the latter method does not extract $\mathrm{H}^{+}$ adsorbed onto the exchange complex in soil colloids. Thus, soil ECa measurements helped to explain the relationship between both methods. 
The high sample density provided by the on-the-go sensor made it possible to compute reliable semivariograms in multiple directions (Figure 9). The semivariogram values revealed a short-range variability in field A and a long-range variability in fields B and C. Except for field B, semivariogram values were smaller in the direction along the track of the measurement. In this direction, measurement values were more connected with each other. This may have been the results of an inter-correlation of measurement errors occurring along track.

Figure 9. Directional experimental semivariograms of the calibrated on-the-go $\mathrm{pH}$ measurements computed in four different directions. The $0^{\circ}$ indicates the direction along the measurement track. The black line denotes the omnidirectional semivariogram model.
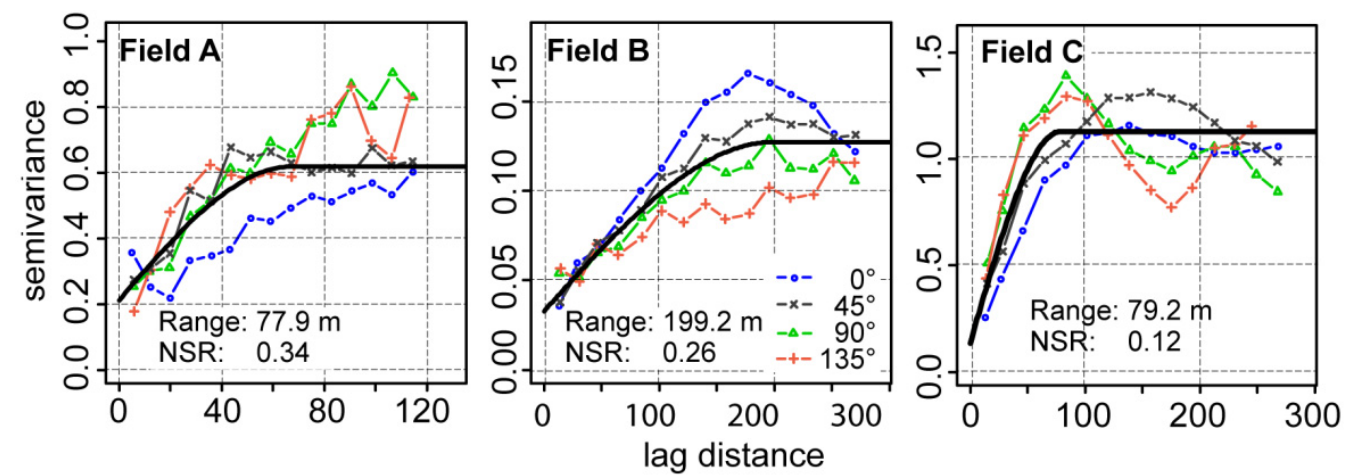

All semivariogram models had NSR values greater than zero. The percentage of the nugget effect on the semivariogram model ranged between 26 and 34\%. The error component of the nugget effect could then be estimated from the residuals of the linear model when regressing the calibrated on-the-go measurements on the lab reference. This showed that the measurement error greatly influenced the nugget effect, with percentages of 49, 68 and $30 \%$ for fields A, B, and C, respectively.

During the field measurements we encountered several types of problems. For example, the soil sampler shoe was blocked by residues and roots of weeds, so that no soil flow was produced through the trough of the shoe. This was observed quite often in field A because the roots of couch grass were accumulated at the front side of the shoe and clogged the entrance. In other cases, the sampler shoe was not correctly within the soil and no new soil material could flow into the trough. Also, the wash nozzles were sometimes displaced by accumulated residues so the electrodes were not washed sufficiently. These mechanical problems caused soil material to be relocated from one point to the other, nonsoil material, such as plant residues, to be measured, and the electrodes to be inadequately cleaned.

Also, it must be mentioned that the soil material is not sufficiently mixed and only soil material along a small furrow is brought upwards to the electrode for measurement. In standard sampling a greater area is covered by several aliquots and the soil material is mixed thoroughly before lab analysis. This reduced sample support can become problematic, when the $\mathrm{pH}$ value varies strongly within small distances because the relevant information is not sufficiently extracted from the spatial pattern of soil $\mathrm{pH}$ in the field [60]. To these sampling and mechanical issues, the fact must be added that the soil $\mathrm{pH}$, obtained with the on-the-go sensor, were systematically higher compared with the lab 
reference and an additional field-specific calibration was necessary to reduce the influences of the sensor electronics and the direct measurement in the soil.

Figure 10 shows the spatial maps computed with Kriging using the on-the-go measurements. All maps showed agreeable surfaces and measurement errors seemed not to produce too many awkward features in the maps. The maps also reflected how sudden changes in soil $\mathrm{pH}$ can occur in the fields.

Figure 10. Soil $\mathrm{pH}$ maps derived from on-the-go sensor readings after calibration to $\mathrm{pH}$ $\left(\mathrm{CaCl}_{2}\right)$. Dots, indicating the measurement locations, are superimposed on raster maps obtained by Kriging interpolation.

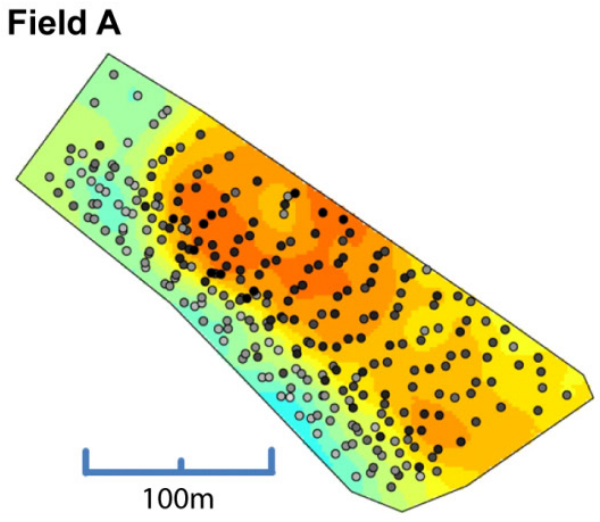

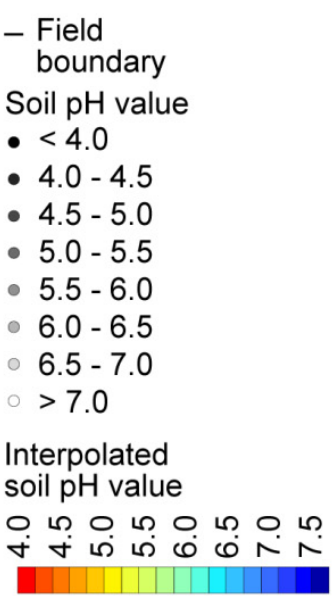

Field C

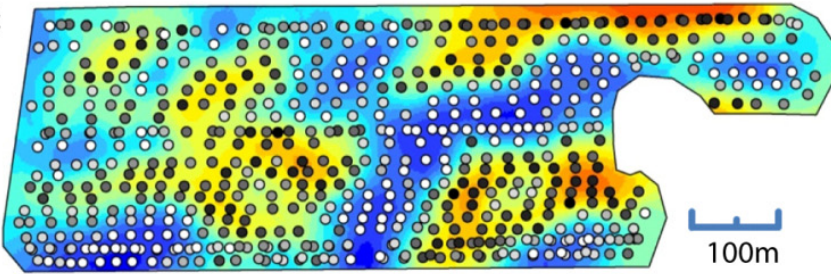

Field B

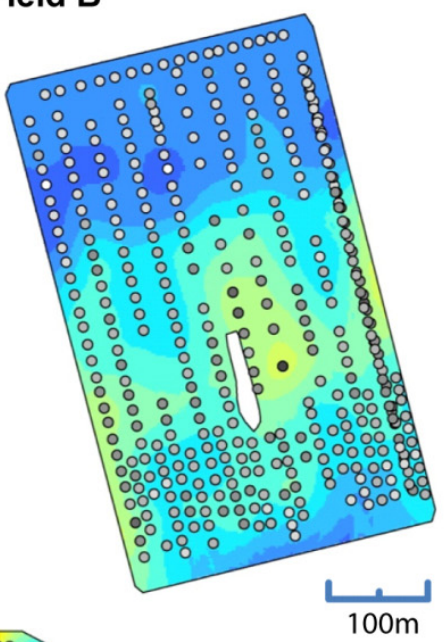

\subsection{Benefit of On-The-Go Mapping Compared with Standard Practical Sampling}

So far, we have only compared the on-the-go measurements with the soil samples that were collected from (approximately) identical locations. But what accuracy can we expect when validated against samples that were not co-located? In Figure 11, a map computed from the on-the-go measurements and a map computed from all of the standard samples is depicted. Between these maps, there is a high degree of similarity, especially for the zone with low $\mathrm{pH}$ values in the middle of the map. Clearly, the left map shows much more detail due to the greater amount of sample points available with on-the-go soil mapping, but one must be aware that some of the features shown in this map can be the result of measurement errors. The observed overall correlation between both maps computed on a grid cell basis was 0.86 (Pearson's r).

Table 4 compares the accuracy from on-the-go soil $\mathrm{pH}$ mapping with the accuracy of standard sampling strategies (whole field (WF) sampling and area composite (AC) sampling). All sampling strategies showed mean errors unequal to zero. WF and AC sampling inherited this bias due to the coarse sampling, and the on-the-go mapping results were biased because of the differences between 
direct soil measurement and lab measurement. On average, on-the-go measurements reduced the error by 0.24 and $0.27 \mathrm{pH}$ units compared with AC and WF sampling, respectively. Surprisingly, the MAE was only slightly increased ( $0.05 \mathrm{pH}$ units) in comparison with the validation of the reference samples above, although the validation samples were taken spatially separated from the sampling positions and up to a soil depth of $0.25 \mathrm{~m}$. Additionally, the measurement accuracy on this field was well in line with results obtained by [39], who reported MAEs between 0.17 and $0.44 \mathrm{pH}$ units.

Figure 11. Soil $\mathrm{pH}$ map of field A computed from calibrated on-the-go sensor readings (1) and soil $\mathrm{pH}$ map computed from standard sampling and lab analysis (2).

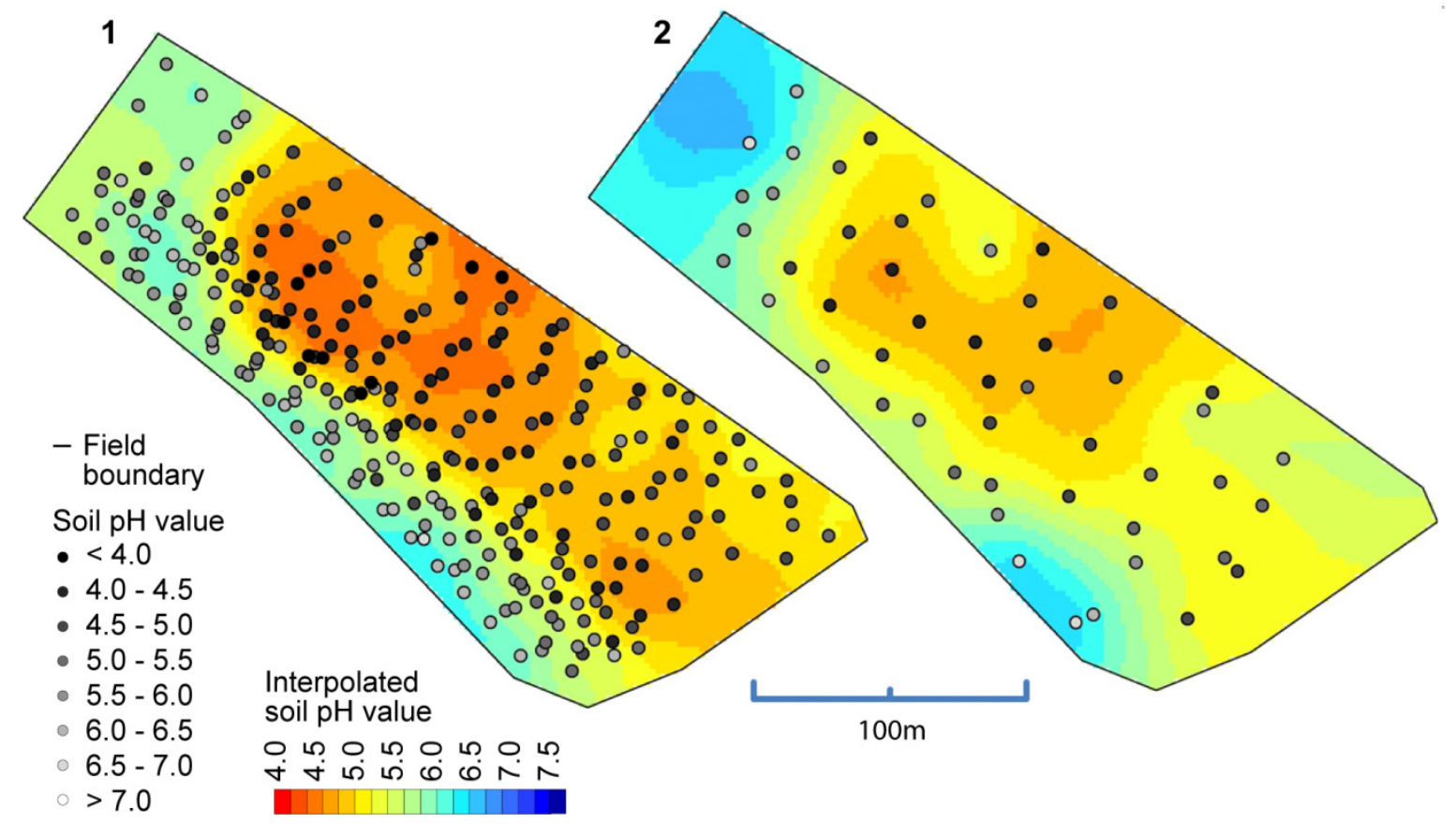

Table 4. Comparison of whole field sampling with on-the-go mapping.

\begin{tabular}{cccc}
\hline Sample strategy & $\begin{array}{c}\text { MAE } \\
(\mathbf{p H})\end{array}$ & $\begin{array}{c}\text { ME } \\
\mathbf{( p H )}\end{array}$ & $\begin{array}{c}\text { Over (+) or under } \\
(-) \text { application of } \\
\text { lime in kg }\end{array}$ \\
\hline map $_{\mathrm{wf}}$ & 0.62 & -0.15 & $-3,643$ \\
map $_{\mathrm{ac}}$ & 0.59 & -0.11 & $-2,855$ \\
map $_{\text {onthego }}$ & 0.35 & 0.20 & $+1,394$ \\
\hline
\end{tabular}

The observed higher accuracy also positively affected the lime recommendation. In total, the absolute error in calculated lime rates was approximately twice as high with WF and AC sampling compared with on-the go mapping because of its more accurate delineation of soil $\mathrm{pH}$ areas. However, the bias was not completely removed by the field-specific calibration and on-the-go mapping estimated a slight over-application of lime for this field. WF sampling, on the other hand, misinterpreted low soil $\mathrm{pH}$ areas and would have resulted in an under-application of lime for this field. 


\section{Conclusions}

Soil pH mapping using an on-the-go soil $\mathrm{pH}$ sensor was successfully carried out on three fields in Northeastern Germany. Preceding tests under controlled conditions demonstrated a high degree of linear relationship between standard laboratory soil $\mathrm{pH}$ values and sensor $\mathrm{pH}$ values. However, these tests also showed that additional calibration is necessary to reduce errors when predicting $\mathrm{pH}\left(\mathrm{CaCl}_{2}\right)$. This is of importance because differences in soil $\mathrm{pH}$ of 0.1 units can lead to differences in lime recommendations of up to $400 \mathrm{~kg} \cdot \mathrm{ha}^{-1} \mathrm{CaO}$.

Under practical field conditions, soil $\mathrm{pH}$ values obtained with the soil $\mathrm{pH}$ sensor were well correlated with lab $\mathrm{pH}\left(\mathrm{CaCl}_{2}\right)$ values. Calibration using 10 reference samples greatly reduced the error between lab $\mathrm{pH}\left(\mathrm{CaCl}_{2}\right)$ and sensor $\mathrm{pH}$. The inclusion of the soil ECa data recorded along with the soil $\mathrm{pH}$ measurements further improved the calibration on one field with high texture variations. After the calibration, mean absolute errors ranged from 0.28 to $0.40 \mathrm{pH}$ units $\left(\mathrm{CaCl}_{2}\right)$. Some of the erroneous measurements were due to mechanical problems that led to blocking of the system by residues and weed roots. To limit these problems, it would be sensible to install a video camera to monitor the sampling process. The driver would then be able to instantly take care of this type of problem. For improving postprocessing, the driver should be able to set a flag at the measurement point where the problem had occurred. Even with these improvements, it can be assumed that individual measurements of an automatic system in the field will be less accurate than $\mathrm{pH}$ values derived from soil analysis in the lab. An on-the-go analysis will only allow for limited control during the $\mathrm{pH}$ measurement.

This uncertainty, however, did not ostensibly influence the maps generated by the sensor $\mathrm{pH}$ values. Our maps showed highly agreeable patterns of soil $\mathrm{pH}$. The comparison with standard maps demonstrated that map accuracy was improved and the error in calculating lime requirement was reduced using soil $\mathrm{pH}$ on-the-go mapping over standard sampling approaches. This was because the higher uncertainty of individual measurements can easily be compensated by the higher sampling density compared with conventional methods [12]. This makes the on-the-go sensor investigated here an interesting alternative for spatially dense sampling strategies when determining the soil $\mathrm{pH}$ variability within the field. Further investigations are necessary to improve the calibration function using additional sensor information as co-variables, such as soil reflectance, soil temperature, and soil humidity.

\section{Acknowledgements}

This research was partly financed by the European Regional Development Fund (ERDF). The authors would like to thank Stephan Palme for giving access to his fields. We acknowledge the support of Christian Thieme, Axel Anlauff, Uwe Frank and Katrin Witzke. The authors appreciate the input from two anonymous referees that allowed us to significantly improve the paper. 


\section{References}

1. Viscarra Rossel, R.A.; McBratney, A.B. Calibration of a lime requirement buffer for site-specific lime applications in south-eastern Australia. In Precision Agriculture '99: Proceedings of the 2nd European Conference on Precision Agriculture Part I; Stafford, J.V., Ed.; Sheffield Academic Press: Sheffield, UK, 1999; pp. 429-440.

2. Gupta, U.C.; Kening, W.U.L.S. Micronutrients in soils, crops, and livestock. Earth Sci. Front. 2010, 15, 110-125.

3. Mengel, K. Agronomic measures for better utilization of soil and fertilizer phosphates. Eur. J. Agron. 1997, 7, 221-233.

4. Bronick, C.J.; Lal, R. Soil structure and management: A review. Geoderma 2005, 124, 3-22.

5. Bünemann, E.K.; Schwenke, G.D.; Van Zwieten, L. Impact of agricultural inputs on soil organisms-A review. Aust. J. Soil Res. 2006, 44, 379-406.

6. Chong, S.-K.; Hildebrand, K.K.; Luo, Y.; Myers, O.; Indorante, S.J.; Kazakevicius, A.; Russin, J. Mapping soybean sudden death syndrome as related to yield and soil/next termsite properties. Soil Till. Res. 2005, 84, 101-107.

7. White, R.E. Principles and Practice of Soil Science: The Soil as a Natural Resource, 4th ed.; Wiley-Blackwell: Malden, MA, USA, 2005; p. 384.

8. Lal, R. Managing soils for a warming earth in a food-insecure and energy-starved world. J. Plant Nutr. Soil Sci. 2010, 173, 4-15.

9. Adamchuk, V.I.; Morgan, M.T.; Loewenberg-Deboer, J.M. A model for agro-economic analysis of soil pH mapping. Prec. Agric. 2004, 5, 111-129.

10. Bongiovanni, R.; Loewenberg-Deboer, J.M. Economics of variable rate lime in Indiana. Prec. Agric. 2000, 2, 55-70.

11. Gebbers, R.; Adamchuk, V.I. Precision agriculture and food security. Science 2010, 327, 828-831.

12. Gebbers, R.; Herbst, R.; Wenkel, K.-O. Sensitivity analysis of soil nutrient mapping. In EFITA Conference '09. Joint International Agricultural Conference (JIAC 2009); Bregt, A., Wolfert, S., Wien, J.E., Lokhorst, C., Eds.; Wageningen Academic Publishers: Wageningen, The Netherlands, 2009; pp. 513-519.

13. Mueller, T.G.; Pierce, F.J.; Schabenberger, O.; Warncke, D.D. Soil sampling for $\mathrm{pH}$ and variable-rate liming. Soil Sci. Soc. Am. J. 2001, 65, 1547-1558.

14. Brouder, S.M.; Hofmann, B.S.; Morris, D.K. Mapping soil pH: Accuracy of common soil sampling strategies and estimation techniques. Soil Sci. Soc. Am. J. 2005, 69, 427-442.

15. Khosla, R.; Westfall, D.G.; Reich, R.M.; Mahal, J.S.; Gangloff, W. Spatial variation and site-specific management zones. In Geostatistical Applications for Precision Agriculture; Oliver, M. A., Ed.; Springer: Dordrecht, The Netherlands, 2010; pp. 195-219.

16. McBratney, A.; Whelan, B.; Ancev, T.; Bouma, J. Future directions of precision agriculture. Prec. Agric. 2005, 6, 7-13.

17. VDLUFA. Georeferenzierte Bodenprobenahme auf landwirtschaftichen Flächen als Grundlage für eine teilflächenspezifische Düngung mit Grundnährstoffen; VDLUFA-Verlag: Darmstadt, Germany, 2000; p. 8. 
18. MAFF. Fertiliser recommendations for agricultural and horticultural crops (RB209), 7th ed.; TSO (The Stationery Office): London, UK, 2000; p. 191.

19. Rehm, G.W.; Lamb, J.A.; Davis, J.G.; Malzer, G.L. P and K grid sampling: What does it yield us? In Proceedings of the 3rd International Conference on Precision Agriculture; Robert, P.C., Rust, R.H., Larson, W.E., Eds.; ASA-CSSA-SSSA: Madison, WI, USA, 1996; pp. 946-956.

20. Griffin, S.J. Directed soil sampling as a means of increasing nutrient map accuracy using complementary precision farming data. In Precision Agriculture '99: Proceedings of the 2nd European Conference on Precision Agriculture Part I; Stafford, J.V., Ed.; Sheffield Academic: Sheffield, UK, 1999; pp. 141-149.

21 Mallarino, A.P.; Wittry, D.J. Efficacy of grid and zone soil sampling approaches for site-specific assessment of phosphorus, potassium, pH, and organic matter. Prec. Agric. 2004, 5, 131-144.

22. Schnug, E.; Haneklaus, S.; Murphy, D.E.P. Equifertiles-An innovative concept for efficient sampling in the local resource management of agricultural soils. Aspects Appl. Biol. 1994, 37, 63-72.

23. Thompson, W.H.; Robert, P.C. Evaluation of mapping strategies for variable rate application. In Proceedings of Site-Specific Management for Agricultural Systems: Second International Conference, Minneapolis, MN, USA, March 27-30, 1994; Robert, P.C., Rust, R.H., Larson, W.E., Eds.; American Society of Agronomy: Madison, WI, USA, 1994; pp. 303-323.

24. Kryzanowski, L. Soil Sampling and Crop Nutrient Requirements: Critical Tools for the Nutrient Management Toolkit; Crop Diversification Centre, North Alberta Agriculture, Food and Rural Development: Edmonton, AB, Canada, 2005; p 8.

25. Düngeverordnung. Verordnung über die Anwendung von Düngemitteln, Bodenhilfsstoffen, Kultursubstraten und Pflanzenhilfsmitteln nach den Grundsätzen der guten fachlichen Praxis beim Düngen (Resolution). Bundesministeriums der Justiz (BMZ), Germany, 27 February 2007.

26. Bramley, R.G.V.; Janik, L.J. Precision agriculture demands a new approach to soil and plant sampling and analysis-Examples from Australia. Commun. Soil. Sci. Plant Anal. 2005, 36, 9-22.

27. Lütticken, R. Automation and standardisation of site specific soil sampling. Prec. Agric. 2000, 2, 179-188.

28. Viscarra Rossel, R.A.; McGlynn, R.N.; McBratney, A.B. Determining the composition of mineral-organic mixes using UV-VIS-NIR diffuse reflectance spectroscopy. Geoderma 2006, 137, 70-82.

29. Pansu, M.; Gautheyrou, J. Handbook of Soil Analysis: Mineralogical, Organic and Inorganic Methods; Springer: Berlin, Germany, 2006; p. 993.

30. Covington, A.K.; Bates, R.G.; Durst, R.A. Definition of pH scales, standard reference values, measurement of $\mathrm{pH}$ and related terminology (recommendations 1984). Pure Appl. Chem. 1985, 57, 531-542.

31. Gründler, P. Chemical Sensors. An Introduction for Scientists and Engineers; Springer: Berlin, Germany, 2007; p. 273.

32. Honold, F.; Honold, B. Ionenselektive Elektroden. Grundlagen und Anwendungen in Biologie und Medizin; Birkhäuser: Basel, Switzerland, 1991; p. 91.

33. Adamchuk, V.I.; Morgan, M.T.; Ess, D.R. An automated sampling system for measuring soil pH. Trans. ASAE 1999, 42, 885-891. 
34. Loreto, A.B.; Morgan, M.T. Development of An Automated System for Field Measurement of Soil Nitrate; Paper No. 961087; ASAE: St. Joseph, MI, USA, 1996.

35. Adamchuk, V.I.; Lund, E.D. On-The-Go Mapping of Soil pH Using Antimony Electrodes; Paper No.083995; ASABE: St. Joseph, MI, USA, 2008.

36. Viscarra Rossel, R.A.V.; Gilbertson, M.; Thylen, L.; Hansen, O.; McVey, S.; McBratney, A.B. Field measurements of soil $\mathrm{pH}$ and lime requirement using an on-the-go soil $\mathrm{pH}$ and lime requirement measurement system. In Precision Agriculture '05. Proceedings of the 5th European Conference on Precision Agriculture, Stafford, J.V., Ed.; Wageningen Academic Publishers: Wageningen, The Netherlands, 2005; pp. 511-520.

37. Sethuramasamyraja, B.; Adamchuk, V.I.; Dobermann, A.; Marx, D.B.; Jones, D.D.; Meyer, G. E. Agitated soil measurement method for integrated on-the-go mapping of soil $\mathrm{pH}$, potassium and nitrate contents. Comput. Electron. Agr. 2008, 60, 212-225.

38. Christy, C.; Collings, K.L.; Drummond, P.D.; Lund, E.D. A Mobile Sensor Platform for Measurement of Soil pH and Buffering; Paper No. 041042; ASABE: St. Joseph, MI, USA, 2004.

39. Adamchuk, V.I.; Lund, E.D.; Reed, T.M.; Ferguson, R.B. Evaluation of an on-the-go technology for soil pH mapping. Prec. Agric. 2007, 8, 139-149.

40. Adamchuk, V.I.; Jonjak, A.K.; Wortmann, C.S.; Shapiro, C.A. A comparison of conventional and sensor-based lime requirement maps. In Proceedings of the 10th International Conference on Precision Agriculture, Denver, CO, USA, July 18-21, 2010; Khosla, R., Ed.; Colorado State University: Denver, CO, USA, 2010; [CD].

41. Veris Technologies Inc. 2010. Available online: http://www.veristech.com/services/ (accessed on 19 October 2010).

42. Gebbers, R.; Lück, E.; Dabas, M.; Domsch, H. Comparison of instruments for geoelectrical soil mapping at the field scale. Near Surface Geophys. 2009, 7, 179-190.

43. Bates, R.G. Electrodes for pH measurement. J. Electroanal. Chem. 1961, 2, 93-109.

44. Conkling, B.L.; Blanchar, R.W. A comparison of $\mathrm{pH}$ measurements using the antimony microelectrode and glass electrode. Agron. J. 1988, 80, 275-278.

45. Glab, S.; Hulanicki, A.; Edwall, G.; Ingman, F. Metal-metal oxide and metal-oxide electrodes as pH sensors. Crit. Rev. Anal. Chem. 1989, 21, 29-47.

46. Baghdady, N.H.; Sommer, K. Application of an improved antimony microelectrode for measuring $\mathrm{pH}$-changes at the soil-root interface of maize. Z. Pflanzenernähr. Bodenkd. 1990, 153, 323-326.

47. Kurzweil, P. Metal oxides and ion-exchanging surfaces as $\mathrm{pH}$ sensors in liquids: State-of-the-art and outlook. Sensors 2009, 9, 4955-4985.

48. VDLUFA. Methodenbuch Band 1, Die Untersuchung von Böden; VDLUFA-Verlag: Darmstadt, Germany, 2004; p. 1470.

49. Roschke, M.; Kohlmüller, S.; Krüger, K.; Pickert, J.; Wurbs, A.; Hierold, W.; Peschke, H. Rahmenempfehlungen zur Düngung 2000 im Land Brandenburg; Ministerium für Landwirtschaft, Umweltschutz und Raumordnung des Landes Brandenburg: Frankfurt (O), Germany, 2010.

50. Shukla, G.K.; Datta, P. Comparison of the inverse estimator with the classical estimator subject to a preliminary test in linear calibration. J. Statist. Plan. Inference 1985, 12, 93-102.

51. Webster, R.; Oliver, M.A. Geostatistics for Environmental Scientists, 2nd ed.; Wiley: Chichester, UK, 2007. 


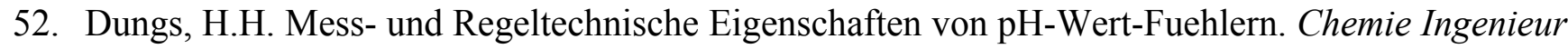
Technik 1956, 28, 656-660.

53. Zezschwitz, E. Praktische Erfahrungen bei der pH-Messung mit der Antimonelektrode zwecks Vereinfachung der Kalkbedarfsbestimmung im Boden. J. Plant Nutr. Soil Sci. 1951, 3, 231-244.

54. Conyers, M.K.; Davey, B.G. Observations on some routine methods for soil-pH determination. Soil Sci. 1988, 145, 29-36.

55. Ahern, C.R.; Baker, D.E.; Aitken, R.L. Models for relating $\mathrm{pH}$ measurements in water and calcium-chloride for a wide-range of $\mathrm{pH}$, soil types and depths. Plant Soil 1995, 171, 47-52.

56. Little, I.P. The relationship between soil-pH measurements in calcium-chloride and water suspensions. Aust. J. Soil Res. 1992, 30, 587-592.

57. Gisi, U.; Schenker, U.; Schulin, R.; Stadelman, F.X.; Sticher, H. Bodenökologie; Georg Thieme Verlag: Stuttgart, Germany, 1990; p. 304.

58. Staggenborg, S.A.; Carignano, M.; Haag, L. Predicting soil $\mathrm{pH}$ and buffer $\mathrm{pH}$ in situ with a real-time sensor. Agron. J. 2007, 99, 854-861.

59. Olfs, H.W.; Borchert, A.; Trautz, D. Validation of on-the-go soil pH measurements-Primary results from germany. In Proceedings of the 10th International Conference on Precision Agriculture, Denver, CO, USA, July 18-21, 2010; Khosla, R., Ed.; Colorado State University: Denver, CO, USA, 2010; [CD].

60. Schirrmann, M.; Domsch, H. Sampling procedure simulating on-the-go sensing for soil nutrients. J. Plant Nutr. Soil Sci. 2010, doi: 10.1002/jpln.200900367.

(C) 2011 by the authors; licensee MDPI, Basel, Switzerland. This article is an open access article distributed under the terms and conditions of the Creative Commons Attribution license (http://creativecommons.org/licenses/by/3.0/). 